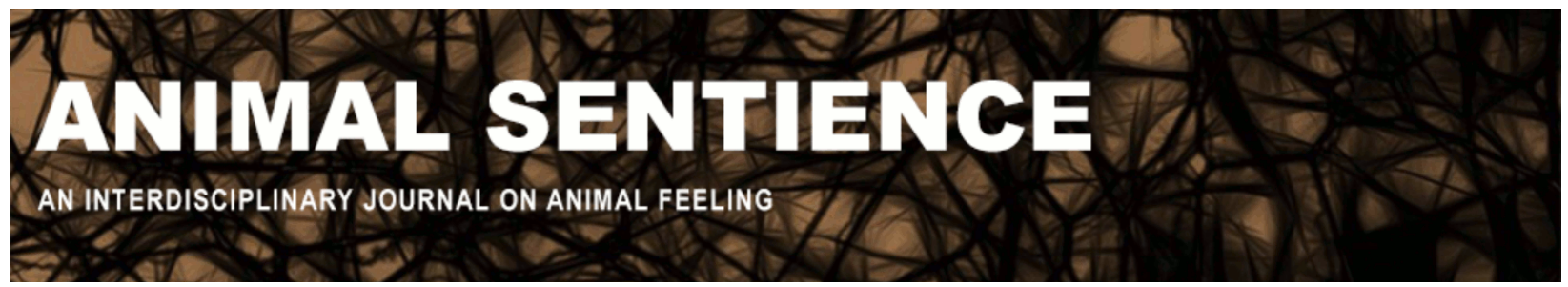

Marino, Lori (2017) The inconvenient truth about thinking chickens. Animal Sentience $17(1)$

DOI: $10.51291 / 2377-7478.1211$

Date of submission: 2017-09-12

Date of acceptance: 2017-09-20

(c)

This article has appeared in the journal Animal

Sentience, a peer-reviewed journal on animal

cognition and feeling. It has been made open access,

free for all, by WellBeing International and deposited

in the WBI Studies Repository. For more information,

please contact

wbisr-info@wellbeingintl.org.

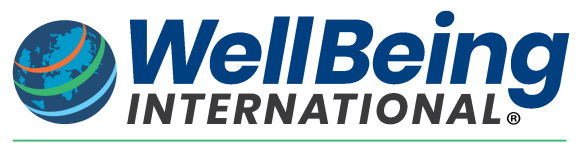

SOLUTIONS FOR PEOPLE, ANIMALS AND ENVIRONMENT 
Call for Commentary: Animal Sentience publishes Open Peer Commentary on all accepted target articles. Target articles are peer-reviewed. Commentaries are editorially reviewed. There are submitted commentaries as well as invited commentaries. Commentaries appear as soon as they have been reviewed, revised and accepted. Target article authors may respond to their commentaries individually or in a joint response to multiple commentaries.

INSTRUCTIONS FOR COMMENTATORS

\title{
The inconvenient truth about thinking chickens
}

\author{
Lori Marino \\ Kimmela Center for Animal Advocacy, Utah
}

Editor's Note: Lori Marino's article is published in Animal Cognition. The article is Open Access. Open Peer Commentary in Animal Sentience is intended primarily for target articles published in Animal Sentience, but in special cases it can be extended to articles that have already been published elsewhere, if it is judged that Open Peer Commentary in Animal Sentience would be useful to the field. Commentators should access the Marino target article online, and then prepare a commentary for Animal Sentience in the same way as when it is published directly in this journal.

\section{Marino, L. (2017). Thinking chickens: A literature review of cognition, emotion, and behavior in the domestic chicken. Animal Cognition, 20(2): 127-141.}

Original Abstract: Domestic chickens are members of an order, Aves, which has been the focus of a revolution in our understanding of neuroanatomical, cognitive, and social complexity. Some birds are now known to be on a par with many mammals in their intelligence, emotional sophistication, and social interaction. Yet views of chickens have largely remained unrevised in light of this new evidence. In this paper, I examine the data on cognition, emotions, personality, and sociality in chickens, exploring such areas as self-awareness, cognitive bias, social learning and self-control, and comparing their abilities with other birds and other vertebrates, particularly mammals. My overall conclusion is that chickens are just as complex cognitively, emotionally and socially as most other birds and mammals in many areas, and that there is a need for further noninvasive comparative behavioral research with chickens as well as a re-framing of current views about their intelligence.

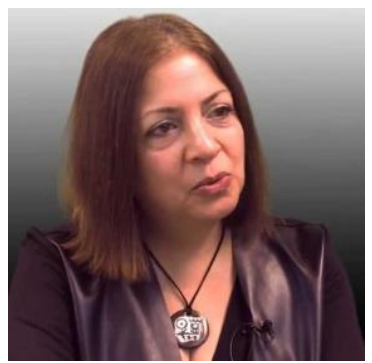

Lori Marino is a neuroscientist, former faculty affiliate at the Emory Center for Ethics, and Executive Director of the Kimmela Center for Animal Advocacy and the Whale Sanctuary Project. She has authored over 130 publications on dolphin and whale brain evolution and anatomy, intelligence and self-awareness, and the effects of captivity on social mammals, including cetaceans, elephants and primates. She worked with the Nonhuman Rights Project and is featured in the films Blackfish and Unlocking The Cage. http://www.kimmela.org 


\section{Rationale for Seeking Open Peer Commentary}

Domestic chickens (Gallus gallus domesticus) are among the most familiar of animals across the globe. They are also among the most exploited as commodities. Ten billion are killed for food annually in the United States alone. Thus, most people never come to know who chickens are on an individual basis and have a psychological investment in not looking too closely at who they are because of their widespread use as food.

The problem with this state of affairs is that chickens remain almost entirely invisible to human awareness. Even when they are the subjects of research, the framework is typically one related to their "management" as a food source. As chicken intelligence, individuality, and complexity are filtered, or even masked, through the lens of their commoditization, it is difficult for people to appreciate chickens for who they are under natural circumstances. As a result, chickens are commonly considered rather unsophisticated animals who do not have enough self-awareness to know or care about how their life is going in such places as factory farms. We also have the unconscious motivation not to want "see" who is on our plates. It is time to present a more informed and authentic view of factory-farmed animals to the public.

The goal of The Someone Project is to bring together what we do know from peer-reviewed scientific studies to present a more complete and authentic portrait of who farmed animals, in this case chickens, are. In Marino (2017) I examined the peer-reviewed scientific data on cognition, emotions, personality, and sociality in chickens, exploring the evidence for selfawareness, cognitive bias, social learning and self-control, and comparing their abilities in these areas with other birds and other vertebrates, particularly mammals. My overall conclusion is that, despite the need for more noninvasive research, the evidence suggests that chickens are just as cognitively, emotionally and socially complex as many other birds and mammals in a wide range of areas.

Therefore, it is no longer tenable to maintain a view of chickens that allows us to heedlessly exploit and abuse them for food. While no animal should be used as a means to an end, the first step towards changing the global exploitation of chickens is to increase awareness about who they are: to make it, if you will, less comfortable for our species to commoditize them and use them for our own purposes.

Call for Commentary: Animal Sentience publishes Open Peer Commentary on all accepted target articles. Target articles are peer-reviewed. Commentaries are editorially reviewed. There are submitted commentaries as well as invited commentaries. Commentaries appear as soon as they have been reviewed, revised and accepted. Target article authors may respond to their commentaries individually or in a joint response to multiple commentaries.

INSTRUCTIONS FOR COMMENTATORS 
Editor's Note: Lori Marino's article is published in Animal Cognition. The article is Open Access. Open Peer Commentary in Animal Sentience is intended primarily for target articles published in Animal Sentience, but in special cases it can be extended to articles that have already been published elsewhere, if it is judged that Open Peer Commentary in Animal Sentience would be useful to the field. Commentators should access the Marino target article online, and then prepare a commentary for Animal Sentience in the same way as when it is published directly in this journal.

Marino, L. (2017). Thinking chickens: A literature review of cognition, emotion, and behavior in the domestic chicken. Animal Cognition, 20(2): 127-141.

To access the target article for commentary, please click above.

\section{References Cited}

Abeyesinghe, S.M., Nicol, C.J., Hartnell, S.J., \& Wathes, C.M. (2005). Can domestic fowl, Gallus gallus domesticus, show self-control? Anim Behav 70:1-11.

Ainslie, G.W. (1974). Impulse control in pigeons. J Exp Anal Behav 21(3):485-489.

Al-Nasser, A., Al-Khalaifa, H., Al-Saffar, A., Khalil, F., Albahouh, M., Ragheb, G., Al-Haddad, A., \& Mashaly, M. (2007). Overview of chicken taxonomy and domestication. World Poult Sci J 63:285-300.

Anderson, M.C., Myowa-Yamakoshi, M., \& Matsuzawa, T. (2004). Contagious yawning in chimpanzees. Proc R Soc B 27(Suppl. 6):S468-S470.

Appleby, M.C., Mench, J.A., \& Hughes, B.O. (2004). Poultry behaviour and welfare. CABI Publishing, Cambridge.

Balcombe, J. (2007). Pleasurable kingdom: animals and the nature of feeling good. McMillan, New York

Barnard, C.(2007). Ethical regulation and animal science: why animal behaviour is special. Anim Behav 74:5-13.

Barrett, L.F. (2006). Are emotions natural kinds? Perspect Psychol Sci 1:28-58.

Barrett, L.F. (2012). Emotions are real. Emotion 12:413-429.

Bateson, M., \& Matheson, S.M. (2007). Performance on a categorization task suggests that removal of environmental enrichment induces 'pessimism' in captive European starlings (Sturnus vulgaris). Anim Welf 16:33-36.

Bayly, K., \& Evans, C.S. (2003). Dynamic changes in alarm call structure: a strategy for reducing conspicuousness to avian predators? Behaviour 140:353-369.

Bechara, A., \& Damasio, A.R. (2005). The somatic marker hypothesis: a neural theory of economic decision. Game Econ Behav 52:336-372.

Bekoff, M. (2005). The question of animal emotions: an ethological perspective. In F.D. McMillan (Ed.), Mental health and well-being in animals (pp. 15-28). Blackwell, Oxford.

Bensky, M.K., Gosling, S.D., \& Sinn, D.L. (2013). The world from a dog's point of view: a review and synthesis of dog cognition research. Adv Study Behav 45:209-406.

Beran M., Pate, J., Washburn, D., \& Rumbaugh, D. (2004). Sequential responding and planning in chimpanzees (Pan troglodytes) and rhesus macaques (Macaca mulatta). J Exp Psychol Anim B 30:203-212.

Beran, M.J. (2002). Maintenance of self-imposed delay of gratification by four chimpanzees (Pan troglodytes) and an orangutan (Pongo pygmaeus). J Gen Psychol 129(1):49-66.

Berwick, R.C., Friederici, A.D., Chomsky, N., \& Bolhuis, J.J. (2013). Evolution, brain and the nature of language. Trends Cogn Sci 17(2):89-98. 
Bird, C.D., \& Emery, N.J. (2008). Using video playback to investigate the social preferences of rooks, Corvus frugilegus. Anim Behav 76:679-687.

Boissy, A., Manteuffel, G., Jensen, M.B., Moe, R.O., Spruijt, B., Keeling, L.J., Winckler, C., Forkman, B., Dimitrov, I., Langbein, J., Bakken, M., Veissier, I., \& Aubert, A. (2007). Assessing positive emotions in animals to improve their welfare. Physiol Behav 92:375-397.

Bonadonna, F., Miguel, E., Grosbois, V., Jouventin, P., \& Bessiere, J.M. (2007). Individual odor recognition in birds: an endogenous olfactory signature on petrels feathers? J Chem Ecol 33:1819-1829.

Boyer, P. (2008). Evolutionary economics of mental time travel?. Trends Cogn Sci 12:219-224.

Boysen, S.T., \& Bernston, G.G. (1990). The development of numerical skills in the chimpanzee. In S.T. Parker \& K.R. Gibson (Eds.), 'Language' and intelligence in monkeys and apes: comparative developmental perspectives (pp. 435-450). Cambridge University Press, Cambridge.

Boysen, S.T., Bernston, G.G., \& Mukobi, K.L. (2001). Size matters: impact of item size and quantity on array of choice by a chimpanzee (Pan troglodytes). J Comp Psychol 115:106-110.

Bradshaw, R.H. (1991). Discrimination of group members by laying hens Gallus domesticus. Behav Process 24:143-151.

Bradshaw, R.H. (1992). Conspecific discrimination and social preference in the laying hen. Appl Anim Behav Sci 33:69-75.

Bradshaw, R.H., \& Dawkins, M.S. (1993). Slides of conspecifics as representatives of real animals in laying hens (Gallus domesticus). Behav Process 28:165-172.

Brannon, E.M., \& Terrace, H.S. (2000). Representation of the numerosities 1-9 by rhesus macaques. J Exp Psychol Anim Behav Process 26:31-49.

Brannon, E.M., Wusthoff, C.J., Gallistel, C.R., \& Gibbon, J. (2001). Numerical subtraction in the pigeon: evidence for a linear subjective number scale. Psychol Sci 12:238-243.

Bräuer, J., Bös, M., Call, J., \& Tomasello, M. (2013). Domestic dogs (Canis familiaris) coordinate their actions in a problem-solving task. Anim Cogn 16:273-285.

Bravo, M., Blake, R., \& Morrison, S. (1988). Cats see subjective contours. Vision Res 28:861-865.

Brodbeck, D.R., Hampton, R.R., \& Cheng, K. (1998). Timing behaviour of black-capped chickadees (Parus atricapillus). Behav Process 44:183-195.

Brown, C. (2015). Fish intelligence, sentience and ethics. Anim Cogn 18(1):1-17.

Brown, S.D., \& Dooling, R.J. (1992). Perception of conspecific faces by budgerigars (Melopsittacus undulatus): I Natural faces. J Comp Psychol 106:203-216.

Bugnyar, T., \& Kotrschal, K. (2002). Observational learning and the raiding of food caches in ravens, Corvus corax: is it 'tactical' deception? Anim Behav 64:185-195.

Bugnyar, T., Kijne, M., \& Kotrschal, K. (2001) Food calling in ravens: are 'yells' referential signals? Anim Behav 61:949-958.

Bulloch, M.J., Boysen, S.T., \& Furlong, E.E. (2008). Visual attention and its relation to knowledge states in chimpanzees, Pan troglodytes. Anim Behav 76:1147-1155.

Burish, M.J., Kueh, H.Y., \& Wang, S.H. (2004). Brain architecture and social complexity in modern and ancient birds. Brain Behav Evol 63:107-124.

Butler, A.B. (2008). Evolution of brains, cognition and consciousness. Brain Res Bull 75:442 -449.

Cabanac, M., \& Aizawa, S. (2000). Fever and tachycardia in a bird (Gallus domesticus) after simple handling. Physiol Behav 69:541-545.

Call, J. (2000). Estimating and operating on discrete quantities in orangs (Pongo pygmaeus). J Comp Psychol 114:136-147.

Campbell, D. (1988). Object permanence in the domestic hen (Gallus domesticus). Honors dissertation, University of Edinburgh.

Chelonis, J.J., Logue, A.W., Sheehy, R., \& Mao, J. (1998). Effects of response effort on self-control in rats. Anim Learn Behav 26:408-415. 
Cheney, D.L., \& Seyfarth, R.M. (1980). Vocal recognition in free-ranging vervet monkeys. Anim Behav 28(2):362-364.

Cheney, D.L., \& Seyfarth, R.M. (1990). How monkeys see the world: inside the mind of another species. University of Chicago Press, Chicago.

Chiandetti, C., \& Vallortigara, G. (2011). Intuitive physical reasoning about occluded objects by inexperienced chicks. Proc R Soc B 278:2621-2627.

Clayton, N.S., \& Dickinson, A. (1998). Episodic-like memory during cache recovery by scrub jays. Nature 395:272-274

Clayton, N.S., Dally, J.M., \& Emery, N.J. (2007). Social cognition by food-caching corvids. The western scrub-jay as a natural psychologist. Philos Trans R Soc B 362:507-522.

Clayton, N.S., Griffiths, D.P., Emery, N.J., \& Dickson, A. (2001). Elements of episodic-like memory in animals. Philos Trans R Soc Lond 356:1483-1491.

Collias, N.E. (1987). The vocal repertoire of red junglefowl: a spectrographic classification and the code of communication. The Condor 89:510-524.

Collias, N.E., \& Joos, M. (1953). The spectrographic analysis of sound signals of the domestic fowl. Behaviour 5:175-188.

Cozzutti, C., \& Vallortigara, G. (2001). Hemispheric memories for the content and position of food caches in the domestic chick. Behav Neurosci 115:305-313.

D’Eath, R.B., \& Stone, R.J. (1999). Chickens use visual cues in social discrimination: an experiment with coloured lighting. Appl Anim Behav Sci 62:233-242.

David, M., Auclair, Y., \& Cezilly, F. (2011). Personality predicts social dominance in female zebra finches, Taeniopygia guttata, in a feeding context. Anim Behav 81:219-224.

Dawkins, M.S. (1995). How do hens view other hens-the use of lateral and binocular visual-fields in social recognition. Behaviour 132:591-606.

Dawkins, M.S., \& Woodington, A. (1997). Distance and the presentation of visual stimuli to birds. Anim Behav 54:1019-1025.

De Souza, A.S., Jansen, J., Tempelman, R.J., Mendl, M., \& Zanella, A.J. (2006). A novel method for testing social recognition in young pigs and the modulating effects of relocation. Appl Anim Behav Sci 99:77-87.

De Waal, F.B.M. (2003). On the possibility of animal empathy. In A.S.R. Manstead, N.H. Frijda, \& A. Fisch (Eds.), Feelings and emotions: the Amsterdam symposium (pp. 377-399). Cambridge University Press, Cambridge.

De Waal, F.B.M. (2008). Putting the altruism back into altruism: the evolution of empathy. Annu Rev Psychol 59:279-300.

Dehaene, S., Spelke, E., Pinel, P., Stanescu, R., \& Tsivkin, S. (1999). Sources of mathematical thinking: behavioral and brain imaging evidence. Science 284:970-974.

Dere, E., Kart-Teke, E., Huston, J.P., \& De Souza Silva, M.A. (2006). The case for episodic memory in animals. Neurosci Biobehav Rev 30:1206-1224.

Dufour, V., Wascher, C.A.F., Braun, A., Miller, R., \& Bugnyar, T. (2011). Corvids can decide if a future exchange is worth waiting for. Biol Lett. doi:10.1098/rsbl.2011.0726.

Dunbar, R.I. (1998). The social brain hypothesis. Brain 9(10):178-190.

Duncan, I.J.H., Slee, G.S., Seawright, E., \& Breward, J. (1989) Behavioural consequences of partial beak amputation (beak trimming) in poultry. Br Poult Sci 30:479-489.

Earp, S.E., \& Maney, D.L. (2012). Birdsong: is it music to their ears? Front Evol Neurosci 4(14):110.

Eddy, T.J., Gallup, G.G., Jr., \& Povinelli, D.J. (1993). Attribution of cognitive states to animals: anthropomorphism in comparative perspective. J Soc Issues 49(1):87-101.

Edgar, J., Held, S., Paul, E., Pettersson, I., I’Anson Price, R., \& Nicol, C. (2015). Social buffering in a bird. Anim Behav 105:11-19. 
Edgar, J.L., Lowe, J.C., Paul, E.S., \& Nicol, C.J. (2011). Avian maternal response to chick distress. Proc R Soc B 278:3129-3134.

Edgar, J.L., Paul, E.S., \& Nicol, C.J. (2013). Protective mother hens: cognitive influence on the avian maternal response. Anim Behav 86(2):223-229.

Eichenbaum, H., Fortin, N.J., Ergorul, C., Wright, S.P., \& Agster, K.L. (2005). Episodic recollection in animals, "If it walks like a duck and quacks like a duck". Learn Motiv 36:190-207.

Emery, N.J. (2006). Cognitive ornithology: the evolution of avian intelligence. Philos Trans R Soc B 361:23-43.

Evans, C.S. (1997). Referential signals. Perspect Ethol 12:99-143.

Evans, C.S. (2002). Cracking the code: communication and cognition in birds. In M. Bekoff, M. Allen, \& G.M. Burghardt (Eds.), The cognitive animal: empirical and theoretical perspectives on animal/cognition (pp. 315-322). MIT Press, Cambridge.

Evans, C.S., \& Evans, L. (1999). Chicken food calls are functionally referential. Anim Behav 58:307319.

Evans, C.S., \& Evans, L. (2007). Representational signaling in birds. Biol Lett 3:8-11.

Evans C.S., Evans, L., \& Marler, P. (1993a). On the meaning of alarm calls: functional reference in an avian vocal system. Anim Behav 46:23-38.

Evans, C.S., Macedonia, J.M., \& Marler, P. (1993b). Effects of apparent size and speed on the response of chickens, Gallus gallus, to computer-generated simulations of aerial predators. Anim Behav 46:1-11.

Favati Leimar, O., Radesater, T., Lovlie, H. (2014b). Social status and personality: stability in social state can promote consistency of behavioral responses. Proc R Soc Biol 281:2015321.

Favati, A., Leimar, O., \& Lovlie, H. (2014a). Personality predicts social dominance in male domestic fowl. PLoS ONE 9(7):e103535.

Feeney, M.C., Roberts, W.A., \& Sherry, D.F. (2009). Memory for what, where, and when in the black-capped chickadee (Poecile atricapillus). Anim Cogn 12:767-777.

Feeney, M.C., Roberts, W.A., Sherry, D.F. (2011). Black-capped chickadees (Poecile atricapillus) anticipate future outcomes of foraging choices. J Exp Psychol Anim Behav 37:30-40.

Ferguson, S.A., Gopee, N.V., Paule, M.G., \& Howard, P.C. (2009). Female mini-pig performance of temporal response differentiation, incremental repeated acquisition, and progressive ratio operant tasks. Behav Process 80:28-34.

Flaherty, C.F., \& Checke, S. (1982). Anticipation of incentive gain. Anim Learn Behav 10:177-182.

Forkman, B. (1998). Hens use occlusion to judge depth in a two-dimensional picture. Perception 27:861-867.

Forkman, B. (2000). Domestic hens have declarative representations. Anim Cogn 3:135-137.

Forkman, B., Boissy, A., Meunier-Slaun, M.C., Canali, E., \& Jones, R.B. (2007). A critical review of fear tests used on cattle, pigs, sheep, poultry and horses. Physiol Behav 92:340-374.

Foster, T.M., Temple, W., Mackenzie, C., DeMello, L.R., \& Poling, A. (1995). Delayed matching-tosample performance of hens: effects of sample duration and response requirements during the sample. J Exp Anal Behav 64(1):19-31.

Fox, R.A., Ladage, L.D., Roth, T.C., \& Pravosudov, V.V. (2009). Behavioural profile predicts dominance status in mountain chickadees, Poecile gambeli. Anim Behav 77:1441-1448.

Fraser, D., Weary, D.M., Pajor, E.A., \& Milligan, B. (1997). A scientific conception of animal welfare that reflects ethical concerns. Anim Welf 6:187-205.

Fraser, O.N., \& Bugnyar, T. (2010). Do ravens show consolation? Responses to distressed others. PLoS ONE 5:e10605. doi:10.1371/journal.pone.0010605.

Frederiksen, J.K., \& Slobodchikoff, C.N. (2007) Referential specificity in the alarm calls of the black-tailed prairie dog. Ethol Ecol Evol 19(2):87-99. 
Freire, F., \& Nicol, C.J. (1997). Object permanence in chicks: predicting the position of an occluded imprinted object. In Abstracts of the ASAB Meeting Biological Aspects of Learning (p. 21). St. Andrew, Scotland, July 1-4.

Freire, R., Munro, U., Rogers, L.J., Sagasser, S., Wiltschko, R., \& Wiltshko, W. (2008). Different responses in two strains of chickens in a magnetic orientation test. Anim Cogn 11:547-552.

Freire, R., \& Nicol, C.J. (1999). Effect of experience of occlusion events on the domestic chick's strategy for locating concealed imprinting object. Anim Behav 58:399-593.

Funk, M.S. (1996). Development of object permanence in the New Zealand parakeet (Cyanoramphus auriceps). Anim Learn Behav 24:375-383.

Gallistel, C.R. (1994). Space and time. In N.J. Mackintosh (Ed.), Animal learning and cognition (pp. 221-253). Academic Press, San Diego.

Gaunet, F., \& Deputte, B.L. (2011). Functional referential and intentional communication in the domestic dog: effects of spatial and social contexts. Anim Cogn 14:849-860.

Gentle, M.J., \& Breward, J. (1986). The bill tip organ of the chicken (Gallus gallus var. domesticus). J Anat 145:79-85.

Gentle, M.J., Hunter, L.N., \& Waddington, D. (1991). The onset of pain related behaviors following partial beak amputation in the chicken. Neurosci Lett 128:113-116.

Gentle, M.J., Waddington, D., Hunter, L.N., \& Jones, R.B. (1990). Behavioural evidence for persistent pain following partial beak amputation in chickens. Appl Anim Behav Sci 27:149-157.

Genty, E., Palmier, C., \& Roeder, J.J. (2004). Learning to suppress responses to the larger of two rewards in two species of lemurs, Eulemur fulvus and E. macaco. Anim Behav 67:925-932.

Gleich, O., \& Langemann, U. (2011). Auditory capabilities of birds in relation to the structural diversity of the basilar papilla. Hear Res 273:80-88.

Gomez, J-C. (2005). Species comparative studies and cognitive development. Trends Cogn Sci 9(3):118-125.

Gosling, S. (2008). Personality in nonhuman animals. Soc Pers Psychol Compass 2:985-1001.

Gosling, S., \& John, O.P. (1999). Personality dimensions in nonhuman animals. Curr Dir Psychol Sci 8:69-75.

Groothuis Ton, G.G., \& Carere, C. (2005). Avian personalities: characterization and epigenesis. Neurosci Biobehav Rev 29:137-150.

Gyger, M., \& Marler, P. (1988). Food calling in the domestic fowl, Gallus gallus: the role of external referents and deception. Anim Behav 36(2):358-365.

Ham, A.D., \& Osorio, D. (2007). Colour preferences and colour vision in poultry chicks. Proc R Soc B 274:1941-1948.

Hatfield, E., Cacioppo, J., \& Rapson, R.L. (1993). Emotional contagion. Curr Dir Psychol Sci 2:96-99.

Hauser, M.D., Carey, S., \& Hauser, L. (2000). Spontaneous number representation in semi-freeranging rhesus monkeys. Proc R Soc London B 267:829-833.

Hazel, S.J., O’Dwyer, L., \& Ryan, T. (2015). "Chickens are a lot smarter than I originally thought": changes in student attitudes to chickens following a chicken training class. Animals 5:821837.

Held, S., Mendl, M., Devereux, C., \& Byrne, R.W. (2000). Social tactics of pigs in a competitive foraging task: the 'informed forager' paradigm. Anim Behav 59:576-579.

Held, S., Mendl, M., Devereaux, C., \& Byrne, R.W. (2002). Foraging pigs alter their behavior in response to exploitation. Anim Behav 64:157-166.

Held S., Cooper, J.J., \& Mendl, M.T. (2009). Advances in the study of cognition, behavioral priorities and emotions. In J.N. Marchant-Forde (Ed.), The welfare of pigs (pp. 47-94). Springer, Netherlands.

Hills, A.M. (1995). Empathy and belief in the mental experience of animals. Anthrozoös 8:132142. 
Hoffman, A., Rūttler V., \& Nieder, A. (2011). Ontogeny of object permanence and object tracking in the carrion crow, Corvus corone. Anim Behav 82(2):359-367.

Hogue, M.E., Beaugrand, J.P., \& Laguë, P.C. (1996). Coherent use of information by hens observing their former dominant defeating or being defeated by a stranger. Behav Process 38(3):241252.

Humphrey, N.K. (1976). The social function of intellect. In G. Bateson \& R.A. Hinde (Eds.), Growing points in ethology (pp. 303-317). University of Cambridge, Cambridge.

Imfeld-Mueller, S., Van Wezemaela, L., Stauffachera, M., Gygax, L., \& Hillmann, E. (2011). Do pigs distinguish between situations of different emotional valences during anticipation? Appl Anim Behav Sci 131:86-93.

Irie-Sugimoto, N., Kobayashi, T., Sato, T., \& Hasegawa, T. (2009). Relative quantity judgement by Asian elephants (Elephas maximus). Anim Cogn 12:193-199.

Iwasaki, S., Watanabe, S., \& Fujita, K. (2013). Do pigeons (Columbia livia) seek information when they have insufficient knowledge? Anim Cogn 16:211-221.

Jaakkola, K., Fellner, W., Erb, L., Rodriguez, M., \& Guarino, E. (2005). Understanding of the concept of numerically "less" by bottlenose dolphins (Tursiops truncatus). J Comp Psychol 119:296303.

Janik, V.M., Sayigh, L.S., \& Wells, R.S. (2006). Signature whistle shape conveys identity information to bottlenose dolphins. Proc Natl Acad Sci USA 103(21):8293-8297.

Jarvis E.D., Güntürkün, O., Bruce, L., Csillag, A., Karten, H., Kuenzel, W., Medina, L., Paxinos, G., Perkel, D.J., Shimizu, T., Striedter, G., Wild, J.M., Ball, G.F., Dugas-Ford, J., Durand, S.E., Hough, G.E., Husband, S., Kubikova, L., Lee, D.W., Mello, C.V., Powers, A., Siang, C., Smulders, T.V., Wada, K., White, S.A., Yamamoto, K., Yu, J., Reiner, A., Butler, A.B.; Avian Brain Nomenclature Consortium. (2005). Avian brains and a new understanding of vertebrate brain evolution. Nat Rev Neurosci 6:151-159.

Joly-Mascheroni, R.M., Senju, A., \& Shepherd, A. (2008). Dogs catch human yawns. Biol Lett 4:446448.

Jones, R.B., \& Roper, T.J. (1997). Olfaction in the domestic fowl: a critical review. Physiol Behav 62(5):1009-1018.

Kaneko, T., \& Tomonaga, M. (2011). The perception of self-agency in chimpanzees (Pan troglodytes). Proc R Soc B 278:2694-2702.

Karakashian, S.J., Gyger, M., \& Marler, P. (1988). Audience effects on alarm calling chickens (Gallus gallus). J Comp Psychol 102(2):129-135.

Kilian, A., Yaman, S., Von Fersen, L., \& Gunturkun, O. (2003). A bottlenose dolphin discriminates visual stimuli differing in numerosity. Learn Behav 31:133-142.

Knight, S., \& Barnett, L. (2008). Justifying attitudes toward animal use: a qualitative study of people's views and beliefs. Anthrozoös 21(1):31-42.

Knight, S., Vrij, A., Cherryman, J., \& Nunkoosing, K. (2004). Attitudes towards animal use and belief in animal mind. Anthrozoös 17(1):43-62.

Kokolakis, A., Smith, C.L., \& Evans, C.S. (2010). Aerial alarm calling by male fowl (Gallus gallus) reveals subtle new mechanisms of risk management. Anim Behav 79:1373-1380.

Koksal, F., \& Domjan, M. (1998). Observational conditioning of sexual behavior in the domesticated quail. Anim Learn Behav 26(4):427-432.

Krachun, C., \& Call, J. (2009). Chimpanzees (Pan troglodytes) know what can be seen from where. Anim Cogn 12:317-331.

Kralj-Fiser, S., Weiss, B.M., \& Kotrschal, K. (2010). Behavioural and physiological correlates of personality in graylag geese (Anser anser). J Ethol 28:363-370.

Lazareva, O.F. (2012). Transitive inference in nonhuman animals. In E.A. Wasserman \& T.R. Zentall (Eds.), The Oxford handbook of comparative cognition, 2nd ed. (pp. 718-735). Oxford University Press, New York. 
Lea, S.E.G., Slater, A.M., \& Ryan, C.M.E. (1996). Perception of object unity in chicks: a comparison with the human infant. Infant Behav Dev 18:501-504.

Lieberman, P. (1994). Human language and human uniqueness. Lang Commun 14:87-95.

Logue, A.W., Smith, M.E., \& Rachlin, H. (1985). Sensitivity of pigeons to pre-reinforcer delay and post-reinforcer delay. Anim Learn Behav 13:181-186.

Luria, A. (1982). Language and cognition. MIT Press, Cambridge.

Macedonia, J.M. (1990). What is communicated in the antipredator call of lemurs: evidence from antipredator call playbacks to ringtailed and ruffed lemurs. Ethology 86:177-190.

Malt, B.C., \& Smith, E.E. (1984). Correlated properties in natural categories. J Verbal Learn Verbal Behav 23(2):250-269.

Marino, L. (2010). Sentience. In M. Breed \& J. Moore (Eds.), Encyclopedia of animal behavior, Vol. 3 (pp. 132-138). Academic Press, Oxford.

Marino, L., \& Colvin, T. (2015) Thinking pigs: a comparative review of cognition, emotion, and personality in Sus domesticus. Int J Comp Psychol 28, uclapsych_ijcp_23859. Retrieved from http://escholarship.org/uc/item/8sx4s79c.

Marler, P., Dufty, A., \& Pickert, R. (1986). Vocal communication in the domestic chicken: I. Does a sender communicate information about the quality of a food referent to a receiver? Anim Behav 34:188-193.

Martin-Ordas, G., Berntsen, D., \& Call, J. (2013). Memory for distant past events in chimpanzees and orangutans. Curr Biol 23(15):1438-1441.

Martin-Ordas, G., Haun, D., Colmenares, F., \& Call, J. (2010). Keeping track of time: evidence for episodic like memory in great apes. Anim Cogn 13:331-340.

Mathews, A., Mogg, K., Kentish, J., \& Eysenck, M. (1995). Effect of psychological treatment on cognitive bias in generalized anxiety disorder. Behav Res Ther 33:293-303.

Mazur, J.E. (2000). Tradeoff among delay, rate and amount of reinforcement. Behav Process 49:110.

McComb, K., Moss, C., Sayialel, S., \& Baker, L. (2000). Unusually extensive networks of vocal recognition in African elephants. Anim Behav 59:1103-1109.

McComb, K., Packer, C., \& Pusey, A. (1994). Roaring and numerical assessment in contests between groups of female lions, Pantera leo. Anim Behav 47:379-387.

McCrae, R.R., \& Costa, P.T. (2008). The five-factor theory of personality. In O.P. John, R.W. Robins, \& L.A. Pervin (Eds.), Handbook of personality (pp. 159-181). Guildford Press, New York.

McLeman, N.A., Mendl, M., Jones, R.B., White, R., \& Wathes, C.M. (2005). Discrimination of conspecifics by juvenile domestic pigs, Sus scrofa. Anim Behav 70:451-461.

Mendl, M., \& Paul, E.S. (2004). Consciousness, emotion and animal welfare: insights from cognitive science. Anim Welf 13:S17-S25.

Mendl, M., Burman, O., Parker, R.M.A., \& Paul, E.S. (2009). Cognitive bias as an indicator of animal emotion and welfare: emerging evidence and underlying mechanisms. Appl Anim Behav Sci 118:161-181.

Mercado, E., III, Murray, S.O., Uyeyama, R.K., Pack, A.A., \& Herman, L.M. (1998). Memory for recent actions in the bottlenosed dolphin (Tursiops truncatus): repetition of arbitrary behaviors using an abstract rule. Anim Learn Behav 26:210-218.

Mervis, C.B., \& Rosch, E. (1981). Categorization of natural objects. Annu Rev Psychol 32:89-115.

Miklósi, Á., Polgárdi, R., Topál, J., \& Csányi, V. (2000). Intentional behaviour in dog-human communication: an experimental analysis of showing behaviour in the dog. Anim Cogn 3:159166.

Miller, K.A. (2003). Behavioral measures of personality in Japanese quail (Coturnix coturnix japonica): reliability, validity, and the effects of four types of environmental enrichment. Ph.D. thesis. Department of Animal Science, University of California, Davis, CA. 
Miller, K.A., Garner, J.P., \& Mench, J.A. (2006). Is fearfulness a trait that can be measured with behavioral tests? A validation of four fear tests for Japanese quail. Anim Behav 71(6):13231334.

Mills, A.D., \& Faure, J.M. (1986). The estimation of fear in domestic quail: correlations between various methods and measures. Biol Behav 11:235-243.

Mischel, W., Shoda, Y., \& Rodriguez, M.L. (1989). Delay of gratification in children. Science 244:933-938.

Molnar, C., Pongracz, P., Farago, T., Doka, A., \& Miklósi, A. (2009). Dogs discriminate between barks: the effects of context and identity of the caller. Behav Process 82:198-201.

Mulcahy, N.J., \& Call, J. (2006). Apes save tools for future use. Science 312:1038-1040.

Nakajima, S., Arimitsu, K., \& Lattal, K.M. (2002). Estimation of animal intelligence by university students in Japan and the United States. Anthrozoos 15(3):194-205.

Nakamura, N., Watanabe, S., \& Fujita, K. (2014). A reversed Ebbinghaus-Titchener illusion in bantams (Gallus gallus domesticus). Anim Cogn 17(2):471-481.

Nakamura, N., Watanabe, S., Betsuyaku, T., \& Fujita, K. (2010). Do bantams (Gallus gallus domesticus) experience amodal completion? An analysis of visual search performance. J Comp Psychol 124(3):331-335.

Nakamura, T., Croft, D.B., \& Westbrook, R.F. (2003). Domestic pigeons (Columba livia) discriminate between photographs of individual pigeons. Learn Behav 31:307-317.

Nicol, C. (2006). How animals learn from each other. Appl Anim Behav Sci 100(1):58-63.

Nicol, C.J. (2015). The behavioural biology of chickens. CABI Publishing, Oxfordshire.

Nicol, C.J., \& Pope, S.J. (1992). Effects of social learning on the acquisition of discriminatory pecking in hens. Bull Psychon Soc 30:293-296.

Nicol, C.J., \& Pope, S.J. (1994). Social learning in small flocks of laying hens. Anim Behav 47:12891296.

Nicol, C.J., \& Pope, S.J. (1999). The effects of demonstrator social status and prior foraging success on social learning in laying hens. Anim Behav 57:163-171.

Nicol, C.J., Caplen, G., Edgar, J., \& Browne, W.J. (2009). Associations between welfare indicators and environmental choice in laying hens. Anim Behav 78:413-424.

Nicol, C.J., Caplen, G., Edgar, J., Richards, G., \& Browne, W.J. (2011a). Relationships between multiple welfare indicators measured in individual chickens across different time periods and environments. Anim Welf 20:133-143.

Nicol, C.J., Caplen, G., Statham, P., \& Browne, W.J. (2011b). Decisions about foraging and risk tradeoffs in chickens are associated with individual somatic response profiles. Anim Behav 82:255262

Nieder, A. (2002). Seeing more than meets the eye: processing of illusory contours in animals. J Comp Physiol A 188(4):249-260.

Nieder, A., \& Wagner, H. (1999). Perception and neuronal coding of subjective contours in the owl. Nat Neurosci 2:660-663.

Osvath, M., \& Osvath, H. (2008). Chimpanzee (Pan troglodytes) and orangutan (Pongo abelii) forethought: self-control and pre-experience in the face of future tool use. Anim Cogn 11:661674.

Ottoni, E.B., \& Mannu, M. (2001). Semifree-ranging tufted capuchins (Cebus apella) spontaneously use tools to crack open nuts. Int J Primatol 22(3):347-358.

Palagi, E., Norscia, I., \& Demuru, E. (2014). Yawn contagion in humans and bonobos: emotional affinity matters more than species. PeerJ 2:e519.

Panksepp, J. (2004). Affective neuroscience: the foundations of human and animal emotions. Oxford University Press, Oxford. 
Parr, L.A., Winslow, J.T., Hopkins, W.D., \& de Waal, F.B. (2000). Recognizing facial cues: individual discrimination by chimpanzees (Pan troglodytes) and rhesus monkeys (Macaca mulatta). J Comp Psychol 114:47-60.

Paul, E.S., Harding, E.J., \& Mendl, M. (2005). Measuring emotional processes in animals: the utility of a cognitive approach. Neurosci Biobehav Rev 29:469-491.

Paz-y-Mino, C.G., Bond, A.B., Kamil, A.C., \& Balda, R.P. (2004). Pinyon jays use transitive inference to predict social dominance. Nature 430:778-781.

Pepperberg, I.M. (1994). Evidence for numerical competence in an African grey parrot (Psittacus erithacus). J Comp Psychol 108:36-44.

Pepperberg, I.M. (2006). Grey parrot numerical competence: a review. Anim Cogn 9:377-391.

Pepperberg, I.M., \& Funk, M.S. (1990). Object permanence in four species of psittacine birds: an African grey parrot (Psittacus erithacus), an Illiger mini macaw (Ara maracana), a parakeet (Melopsittacus undulatus), and a cockatiel (Nymphicus hollandicus). Anim Learn Behav 18:97108.

Peterhans, E., \& von der Heydt, R. (1989). Mechanisms of contour perception in monkey visual cortex: II. Contours bridging gaps. J Neurosci 9:1749-1763.

Phillips, C.J.C., \& McCulloch, S. (2005). Student attitudes on animal sentience and use of animals in society. J Biol Educ 40(1):17-24.

Piaget, J. (1928). Judgment and reasoning in the child. Harcourt, Brace and Co, New York.

Piaget, J. (1953). Origin of intelligence in the child. Routledge \& Kegan Paul, London.

Piaget, J. (1964). Part I: Cognitive development in children: Piaget development and learning. J Res Sci Teach 2(3):176-186.

Pizzari, T. (2003). Food, vigilance, and sperm: the role of male direct benefits in the evolution of female preference in a polygamous bird. Behav Ecol 14:593-601.

Plowright, C.M.S., Reid, S., \& Kilian, T. (1998). Finding hidden food: behavior on visible displacement tasks by mynahs (Gracula religiosa) and pigeons (Columbia livia). J Comp Psychol 112:13-25.

Polari, R., Total, J., \& Scania, V. (2000). Intentional behaviour in dog-human communication: an experimental analysis of "showing" behaviour in the dog. Anim Cogn 3(3):159-166.

Pollok, B., Prior, H., \& Güntürkün, O. (2000). Development of object permanence in food-storing magpies (Pica pica). J Comp Psych 114(2):148-157.

Premack, D. (1975). On the origins of language. In M.S. Gazzaniga \& C.B. Blackmore (Eds.), Handbook of psychobiology (pp. 591-605). Academic Press, New York.

Preston, S.D., \& de Waal, F.B.M. (2002) Empathy: its ultimate and proximate bases. Behav Brain Sci 25:1-2.

Raby, C.R., Alexis, D.M., Dickinson, A., \& Clayton, N.S. (2007). Planning for the future by western scrubjays. Nature 445:919-921.

Rachlin, H., \& Green, L. (1972). Commitment, choice and self-control. J Exp Anal Behav 17:15-22.

Rauw, W.M., Kanis, E., Noordhuizen-Stassen, E.N., \& Grommers, F.J. (1998). Undesirable side effects of selection for high production efficiency in farm animals: a review. Livest Sci 56:1533.

Reale, D., Reader, S.M., Sol, D., McDougall, P.T., \& Dingemanse, N.J. (2007). Integrating animal temperament within ecology and evolution. Biol Rev Camb Philos 82(2):291-318.

Regolin, L., \& Vallortigara, G. (1995). Perception of partly occluded objects by young chicks. Percept Psychophys 57(7):971-976.

Regolin, L., Tommasi, L., \& Vallortigara, G. (2000). Visual perception of biological motion in newly hatched chicks as revealed by an imprinting procedure. Anim Cogn 3:53-60.

Regolin, L., Vallortigara, G., \& Zanforlin, M. (1994). Perceptual and motivational aspects of detour behaviour in young chicks. Anim Behav 47:123-131. 
Regolin, L., Vallortigara, G., \& Zanforlin, M. (1995). Detour behaviour in the domestic chick: searching for a disappearing prey or a disappearing social partner. Anim Behav 50:203-211.

Reimert, I., Bolhuis, J.E., Kemp, B., \& Rodenburg, T.B. (2014). Emotions on the loose: emotional contagion and the role of oxytocin in pigs. Anim Cogn 18:517-532.

Richelle, M., \& Lejeune, H. (1980). Time in animal behavior. Pergamon Press, Oxford.

Roberts, W.A., Cheng, K., \& Cohen, J.S. (1989). Timing light and tone signals in pigeons. J Exp Psychol Anim Behav Process 15:23-35.

Romero, T., Ito, M., Santo, A., \& Hasegawa, T. (2014). Social modulation of contagious yawning in wolves. PLoS ONE 9(8):e105963.

Rugani, R., Fontanari, L., Simoni, E., Regolin, L., \& Vallortigara, G. (2009). Arithmetic in newborn chicks. Proc R Soc B 276:2451-2460.

Rugani, R., Regolin, L., \& Vallortigara, G. (2007). Rudimental numerical competence in 5-day-old domestic chicks: identification of ordinal position. J Exp Psychol Anim B 33:21-31.

Rugani, R., Regolin, L., \& Vallortigara, G. (2008). Discrimination of small numerosities in young chicks. J Exp Psychol Anim B 34:388-399.

Rugani, R., Regolin, L., \& Vallortigara, G. (2010). Imprinted numbers: newborn chicks' sensitivity to number vs. continuous extent of objects they have been reared with. Dev Sci 13:790-797.

Rugani, R., Vallortigara, G., Priftis, K., \& Regolin, L. (2015). Number-space mapping in the newborn chick resembles humans' mental number line. Science 347(6221):534-536.

Ryan, C.M.E., \& Lea, S.E.G. (1994). Images of conspecifics as categories to be discriminated by pigeons and chickens: slides, video tapes, stuffed birds and live birds. Behav Process 33:155176.

Savory, C.J., Wood-Gush, D.G.M., \& Duncan, I.J.H. (1978). Feeding behaviour in a population of domestic fowls in the wild. Appl Anim Ethol 4:13-27.

Sawai, H., Kim, H.L., Kuno, K., Suzuki, S., Goto, H., Takada, M., Takahata, M., Satta, Y., \& Akishinonomiya, F. (2010). The origin and genetic variation of domestic chickens with special reference to junglefowls Gallus g. gallus and G. varius. PLOS ONE 5(5):e10639.

Sayigh, L.S., Tyack, P.L., Wells, R.S., Solow, A.R., Scott, M.D., \& Irvine, A.B. (1999). Individual recognition in wild bottlenose dolphins: a field test using playback experiments. Anim Behav 57:41-50.

Schuett, W., Dall, S.R., \& Royle, N.J. (2011). Pairs of zebra finches with similar 'personalities' make better parents. Anim Behav 81(3):609-618.

Schwartz, B.L., Hoffman, M.L., \& Evans, S. (2005). Episodic-like memory in a gorilla: a review and new findings. Learn Motiv 36:226-244.

Seyfarth, R.M., Cheney, D.L., \& Marler, P. (1980). Monkey responses to three different alarm calls: evidence of predator classification and semantic communication. Science 210:801-803.

Shettleworth, S.J. (2010). Cognition, evolution, and behavior, 2nd ed. Oxford University Press, Oxford.

Shimp, C.P. (1982). On metaknowledge in the pigeon: an organism's knowledge about its own behavior. Anim Learn Behav 10:358-364.

Singer, T. (2006). The neuronal basis and ontogeny of empathy and mind reading: review of literature and implications for future research. Neurosci Biobehav Rev 30:855-863.

Slobodchikoff, C.N. (2012). Chasing Doctor Dolittle: learning the language of animals. Marten's Press, New York.

Slocombe, K.E., \& Zuberbühler, K. (2005). Functionally referential communication in a chimpanzee. Curr Biol 15(19):1779-1784.

Smirnova, A.A., Lazareva, O.F., \& Zorina, Z.A. (2000). Use of number by crows: investigation by matching and oddity learning. J Exp Anim Beh 73:163-176.

Smith, C.L., Taylor, A., \& Evans, C.S. (2011). Tactical multimodal signaling in birds: facultative variation in signal modality reveals sensitive to social costs. Anim Behav 82:521-527. 
Sovrano, V.A., \& Bisazza, A. (2009). Perception of subjective contours in fish. Perception 38:579590.

Spinka, M., Duncan, I.J.H., \& Widowski, T.M. (1998). Do domestic pigs prefer short-term to medium-term confinement? Appl Anim Behav Sci 58:221-232.

Stephens, D.W. (2008). Decision ecology: foraging and the ecology of animal decision making. Cogn Affect Behav Neurosci 8:475-484.

Struhsaker, T.T. (1967). Auditory communication among vervet monkeys (Cercopithecus aethiops). In S.A. Altmann (Ed.), Social communication among primates (pp. 281-324). University of Chicago Press, Chicago.

Suddendorf, T., \& Corballis, M.C. (2007). The evolution of foresight: what is mental time travel and is it unique to humans? Behav Brain Sci 30:299-351.

Taylor, P.E., Haskell, M., Appleby, M.C., \& Waran, N.K. (2002). Perception of time duration by domestic hens. Appl Anim Behav Sci 76:41-51.

Templeton, C.N., Greene, E., \& David, K. (2005). Allometry of alarm calls: black-capped chickadees encode information about predator size. Science 208:1934-1937.

Towner, S. (2010). Concept of mind in non-human primates. Biosci Horiz 3:96-104.

Tulving, E. (2005). Episodic memory and autonoesis: uniquely human? In H.S. Terrace \& J. Metcalfe (Eds.), The missing link in cognition (pp. 3-56). Oxford University Press, Oxford.

Udell, M.A.R., Dorey, N.R., \& Wynn, C.L.D. (2010). What did domestication do to dogs? A new account of dogs' sensitivity to human actions. Biol Rev 85:327-345.

Uller, C., \& Lewis, J. (2009). Horses (Equus caballus) select the greater of two quantities in small numerical contrasts. Anim Cogn 12:733-738.

UN's Food and Agriculture Organisation. Reported in the Economist: http://www.economist.com/blogs/dailychart/2011/07/global-livestock-counts.

Väisänen, J., Lindqvist, C., \& Jensen, P. (2005). Co-segregation of behaviour and production related traits in an F3 intercross between red junglefowl and White Leghorn laying hens. Br Poult Sci 46:156-158.

Vallortigara, G., \& Regolin, L. (2002). Facing an obstacle: laterialization of object and spatial cognition. In R.J. Andrew, \& L.J. Rogers (Eds.), Comparative vertebrate lateralization (pp. 383444). Cambridge University Press, Cambridge.

Vallortigara, G., Regolin, L., Chiandetti, C., \& Rugani, R. (2010). Rudiments of mind: insights through the chick model on number and space cognition in animals. Comp Cogn Behav Rev 5:78-99.

Vallortigara, G., Regolin, L., Rigoni, M., \& Zanforlin, M. (1998). Delayed search for a concealed imprinted object in the domestic chick. Anim Cogn 1:17-24.

van Hateren, J.H., Srinivasan, M.V., \& Wait, P.B. (1990). Pattern recognition in bees: orientation discrimination. J Comp Physiol A 167:649-654.

Vasconcelos, M. (2008). Transitive inference in nonhuman animals: an empirical and theoretical analysis. Behav Process 78:313-334.

Walden, T.A., \& Ogan, T.A. (1988). The development of social referencing. Child Dev 59(5):12301240.

Wascher, C.A.F., Scheiber, I.B.R., \& Kotrschal, K. (2008). Heart rate modulation in bystanding geese watching social and non-social events. Proc R Soc B 275:1653-1659.

Watanabe, A., Grodzinski, U., \& Clayton, N.S. (2013). Western scrub-jays allocate longer observation time to more valuable information. Anim Cogn 17(4):859-867.

Weiß, B.M., Kehmeier, S., \& Schloegl, C. (2010). Transitive inference in free-living graylag geese (Anser anser). Anim Behav 79(6):1277-1283.

West, B., \& Zhou, B.X. (1988). Did chickens go North? New evidence for domestication. J Archaeol Sci 15:515-533. 
Whitehead, H., \& Rendell, L. (2015). The cultural lives of whales and dolphins. University of Chicago Press, Chicago.

Whiten, A., \& Byrne, R.W. (1997). Machiavellian intelligence II. Cambridge University Press, Cambridge.

Whitfield, D.P. (1987). Plumage variability, status signaling, and individual recognition in avian flocks. Trends Ecol Evol 2:13-18.

Wichman, A., Keeling, L.J., \& Forkman, B. (2012). Cognitive bias and anticipatory behavior of laying hens housed in basic and enriched pens. Appl Anim Behav Sci 140:62-69.

Wilson, D.R., \& Evans, C.S. (2008). Mating success increases alarm-calling effort in male fowl, Gallus gallus. Anim Behav 76:2029-2035.

Wood, S.T., Sanderson, K.J., \& Evans, C.S. (2000). Perception of terrestrial and aerial alarm calls by honeyeaters and falcons. Aust J Zool 48:127-134.

Wu, H.M., Sackett, G.P., \& Gunderson, V.M. (1986). Social stimuli as incentives for delayed response performance by infant pigtailed macaques (Macaca nemestrina). Primates 27:229-236.

Wyzisk, K., \& Neumeyer, C. (2007). Perception of illusory surfaces and contours in goldfish. Vis Neurosci 24:291-298.

Yamamoto, S., Humley, T., \& Tanak, M. (2013). Basis for cumulative cultural evolution in chimpanzees: social learning of a more efficient tool-use technique. PLoS ONE 8(1):e55768.

Zanforlin, M. (1981). Visual perception of complex forms (anomalous surfaces) in chicks. Ital J Psychol 8:1-16.

Zeiler, M.D., \& Powell, D.G. (1994). Temporal control in fixed-interval schedules. J Exp Anal Behav 61:1-9.

Zentall, T.R. (2012). Perspectives on observational learning in animals. J Comp Psychol 126(2):114-128.

Zentall, T.R., Clement, T.S., Bhatt, R.S., \& Allen, J. (2001). Episodic-like memory in pigeons. Psychon Bull Rev 8(4):685-690.

Zimmerman, P.H., Buijs, S.A.F., Bolhuis, J.E., \& Keeling, L.J. (2011). Behavior of domestic fowl in anticipation of positive and negative stimuli. Anim Behav 81:569-577.

Zuberbühler, K. (2000). Causal knowledge of predators' behaviour in wild Diana monkeys. Anim Behav 59:209-220.

Zucca, P., Milos, N., \& Vallortigara, G. (2007). Piagetian object permanence and its development in Eurasian jays (Garrulus glandarius). Anim Cogn 10:243-258.

Call for Commentary: Animal Sentience publishes Open Peer Commentary on all accepted target articles. Target articles are peer-reviewed. Commentaries are editorially reviewed. There are submitted commentaries as well as invited commentaries. Commentaries appear as soon as they have been reviewed, revised and accepted. Target article authors may respond to their commentaries individually or in a joint response to multiple commentaries.

INSTRUCTIONS FOR COMIMENTATORS 
Call for Commentary: Animal Sentience publishes Open Peer Commentary on all accepted target articles. Target articles are peer-reviewed. Commentaries are editorially reviewed. There are submitted commentaries as well as invited commentaries. Commentaries appear as soon as they have been reviewed, revised and accepted. Target article authors may respond to their commentaries individually or in a joint response to multiple commentaries. Instructions: http://animalstudiesrepository.org/animsent/guidelines.html

[Editorial note: Animal Sentience and does not publish primary research reports of findings from experiments that hurt animals. In the context of open peer commentary, however, including criticism of findings from such experiments, secondary references to findings already published elsewhere are unavoidable.]

\title{
Consciousness in teleosts: There is something it feels like to be a fish
}

\author{
Michael L. Woodruff \\ Departments of Biomedical Sciences and Psychology, East Tennessee State University
}

\begin{abstract}
Ray-finned fish are often excluded from the group of non-human animals considered to have phenomenal consciousness. This is generally done on the grounds that the fish pallium lacks a sufficiently expansive gross parcellation, as well as even minimally sufficient neuronal organization, intrinsic connectivity, and reciprocal extrinsic connections with the thalamus to support the subjective experience of qualia. It is also argued that fish do not exhibit the level of behavioral flexibility indicative of consciousness. A review of neuroanatomical, neurophysiological and behavioral studies is presented which leads to the conclusion that fish do have neurobiological correlates and behavioral flexibility of sufficient complexity to support the hypothesis that they are capable of phenomenal consciousness.
\end{abstract}

Keywords: comparative consciousness, phenomenal consciousness, fish, pallium,

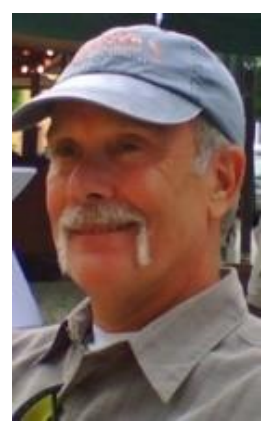
comparative anatomy, comparative behavior

Michael L. Woodruff is Professor Emeritus of Biomedical Sciences and of Psychology at East Tennessee State University. Author of more than 120 professional publications, his research interests include cognitive neuroscience and the philosophy of mind. https://michaelwoodruff.academia.edu/ 
Animal Sentience 2017.010: Woodruff on Fish Feel 


\section{INTRODUCTION}

Two connected theses will be defended in this paper. The first thesis is that ray-finned fishes of the teleost subclass (Actinopterygii; hereafter referred to simply as fishes) ${ }^{1}$ are sentient. The second thesis is that the pallium contributes to sentience in these species. Allen and Trestman (2016) equate phenomenal consciousness and sentience. I will adapt their use of the term and define sentience ${ }^{2}$ as at least the minimal capacity to have subjective experience of the qualities associated with external and internal sensations, as well as affective and motivational states. The consequence of this capacity is that there is something that it "feels like" to be the individual, human or animal, that has subjective experience (Nagel 1974).

I argue that there is something it feels like to be a fish. Others disagree, and usually ground their disagreement on two general arguments. The first argument is that fishes lack the neuroanatomical substrates necessary for consciousness. This argument assumes that a layered neocortex, or a structure homologous to it, with a number of anatomically distinct divisions and reciprocal anatomical connections among them, is required for even minimal sentience. Furthermore, massive reciprocal connections between the neocortex and the thalamus are needed. Because the fish pallium is not homologous to the mammalian neocortex, and its reciprocal connections with the thalamus are sparse, fishes lack the required neuroanatomical substrates for sentience (Cabanac et al. 2009; D. Edelman et al. 2005; Key 2015, 2016a; Rose 2002, 2007; Rose et al. 2012; Seth et al. 2005). The second argument follows naturally from the first. It is that fishes do not exhibit behaviors that require sentience. On this view, all of the behaviors observed in fishes, regardless of how complex they appear to be, are explicable by reference to simple sensory-motor reflexes, speciestypical behaviors, or procedural/implicit learning and memory. I contend that both of these arguments fail.

In this target article I will present research supporting the hypothesis that the fish brain is neuroanatomically complex enough to support sentience. I will also present evidence that the pallium of the fish has neurophysiological activity similar to correlates of sentience in mammals. Finally, I will provide selected examples of behaviors generally thought to require sentience in humans.

\section{SENTIENCE IN FISHES: THE OPTIC TECTUM}

Several theories propose that sentience emerged in animals when the hindbrain, midbrain and diencephalic nuclei first evolved (e.g., Damasio 2010; Feinberg and Mallatt 2013, 2016; Merker 2007; Panksepp 2005). These theories differ in neuroanatomical detail and in the physiological and behavioral processes they emphasize. They will not be reviewed here (see Feinberg and Mallatt 2016, chapter 7, for a discussion). However, they have the following in common: (i) proposing that at least minimal sentience is possible without a neocortex, and (ii) attributing a role in the generation of sentience to the optic tectum.

\footnotetext{
${ }^{1}$ Cartilaginous fishes, such as sharks and rays, from the class chondrichtyans are not included in this discussion.

${ }^{2}$ What I am calling sentience is, in general, the same process that Feinberg and Mallatt (2016) call sensory consciousness and that G. Edelman (1989) refers to as primary consciousness.
} 


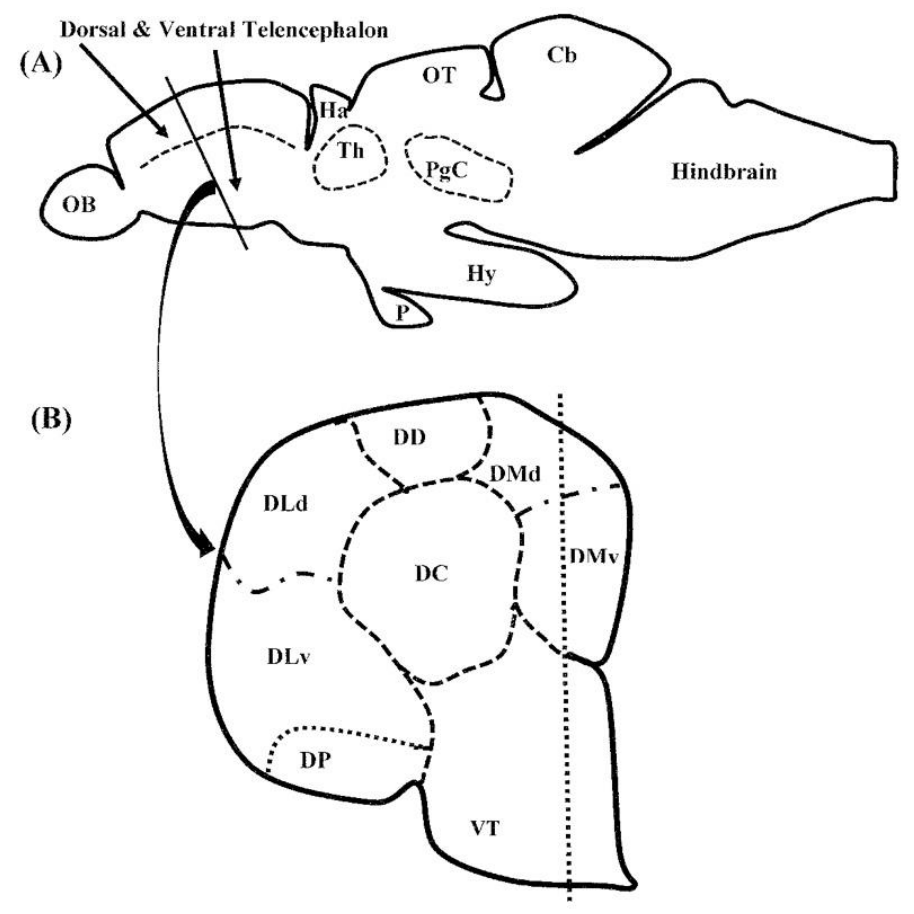

Figure 1. The drawings in this figure are provided as aids in visualizing the physical relationships among the major divisions of the fish brain discussed in the text. They are generalized representations and may therefore deviate in detail from the specific descriptions given in the cited references. (A) Schematic of a longitudinal (sagittal) section of the fish brain. The drawing represents a parasagittal section from the location of the dashed line in (B). That is, it comes from a location slightly away from the midline of the brain. Abbreviations: $\mathrm{Cb}$ - cerebellum; Ha - habenula; $\mathrm{Hy}$ hypothalamus; OB - olfactory bulb; OT - optic tectum; Th - thalamus; P - pituitary; PgC - preglomerular complex. (B) A schematic cross section from the dorsal through the ventral surface of one hemisphere of the fish telencephalon. The section is drawn to represent the approximate anterior-posterior level of the brain demarcated by the vertical line in (A). It shows the locations of the pallial divisions given by Nieuwenhuys and Meek (1990). Abbreviations (all beginning with D refer to divisions of the pallium): DD - dorsodorsal; DMd - dorsomedial dorsalis; DLv dorsomedial ventralis; DLd - dorsolateral dorsalis; DC - dorsalis centralis; DP dorsalis posterior; VT - ventral (subpallial) telencephalon; DMv - dorsomedial ventralis.

The fish optic tectum (Figure 1A) is more involved in sensorimotor integration in fishes than its homolog, the superior colliculus, is in mammals. All sensory modalities present in any given teleost species, with the exception of olfaction, are represented in the tectum. However, visual input is especially strong and the tectum is generally viewed as the primary 
visual center in fishes (Feinberg and Mallatt 2013, 2016; Li 2016; Meek 1983). As such, the tectum is crucial for the transformation of visual input into directed, adaptive global motor output. This transformation begins with the creation of an accurate point-by-point representation of visual space on the retina. Feinberg and Mallatt (2016) refer to this representation as sensory isomorphism. Retinal input to the tectum generates an isomorphic neural representation of visual space. Feinberg and Mallatt take it as axiomatic "that mental images are a part of primary, sensory consciousness and, therefore, contribute to "something it is like to be.) The neural representation of the world in the tectum is experienced subjectively as mental images. On my view, this is an important insight into what it means for a neural system to participate in the generation of sentience.

\subsection{Tectal Neuroanatomy}

But what evidence is there that the optic tectum is a crucial part of such a neural system? Others, in particular Feinberg and Mallatt $(2013,2016)$ and Merker (2007), have provided extensive reviews of this evidence. I will not replicate these reviews, but will provide a brief account of data indicating that the optic tectum, and its extrinsic and intrinsic connections, meet the requirements to be an anatomical substrate of sentience in fishes. I will discuss only the visual modality, but the basic organizational pattern also applies to the other sensory modalities represented in the tectum.

One requirement is that the visual world be accurately represented in the tectum. Isomorphic retinal input mediated by the excitatory neurotransmitter glutamate terminates primarily in the uppermost of the six neuronal layers of the tectum on the opposite side of the brain. Both anatomical and electrophysiological studies indicate that the pattern of termination reflects the accurate point-by-point visual representation of the world created on the retina (Nevin et al. 2010; Meek 1983; Venegas and Ito, 1983). Another requirement is modulation of the primary sensory pathways by intrinsic excitatory and inhibitory interneurons. Primary sensory input to the tectum can be amplified by positive feedforward and feedback circuits created by excitatory glutaminergic interneurons. Intrinsic inhibitory circuits created by interneurons that use $\gamma$-aminobutyric acid (GABA) as a transmitter provide for temporal stabilization and spatial sharpening of activity within the excitatory circuits (Kardamakisa et al. 2015; Nevin et al. 2010). One function of these inhibitory circuits may be to improve discriminability of objects in the fish's visual field. Ablation of these neurons selectively impairs prey capture in zebrafish (Del Bene et al. 2010), possibly because the prey is perceived as larger than it is and because predator avoidance rather than prey approach behavior is selected (Barker and Baier 2015).

The tectum also receives input from mesencephalic and hindbrain nuclei, as well as the diencephalic and telencephalic regions, including the pallium. As will be discussed below, this input allows memory and emotion to influence tectal output to brainstem structures that regulate motor programs. The output of the tectum arises from neurons located in its deeper layers. This output terminates in the telencephalic, diencephalic, and brainstem sites that provide input to the tectum, and, most importantly, in premotor brainstem nuclei that directly control behavior. These nuclei send input back to the tectum, thereby providing rapid feedback to refine future output (Kinoshita et al. 2006; Meek 1983; Nevin et al. 2010; Sato et al. 2007). 
In sum, the extrinsic reciprocal neuronal connections and the intrinsic neuroanatomy of the teleost tectum are complex enough to support the reentrant computational processes proposed to underlie sentience in mammals (Crick and Koch 2003; G. Edelman 1989; G. Edelman et al. 2011; Seth et al. 2005). In mammals, neural and behavioral markers of such computational processes are associated with the neocortex and its connections to the thalamus. If the conclusion reached above is correct, then it should be possible to find similar markers associated with the tectum of fishes. Here I will provide a specific example.

\subsection{Selective Attention and Tectal Neurophysiology}

Feinberg and Mallat (2016) include "mechanisms for selective attention to stimuli" as one of their criteria for sensory consciousness, the process that I am calling sentience. Selective attention may be a legitimate criterion for the presence of sentience, but researchers in this area do not agree as to how this may be. Sentience and selective attention are generally not considered to be the same process, and evidence indicates that either can be present without the other (Baars 1997; van Boxtel et al. 2010; Howe et al. 2009; Tononi and Koch 2015). However, it seems undeniable that the two are related. I suggest that some form of sentient pre-attentional awareness of the world exists as long as an adequate level of arousal and general, nonspecific awareness of the environment are present. However, in the absence of selective attention, the contents of sentience required to produce specific actions necessary for survival, such as finding food or avoiding a predator, are absent. On this view, then, selective attention varies the force and focus of sentience. The implication is that, if sentience did not exist, then the processes of selective attention would have no work to do. Therefore, they would not exist. But it is indisputable that they do. Thus, agreeing with Feinberg and Mallatt, I argue that selective attention is a legitimate criterion for the presence of sentience.

A principal function of selective attention in the visual modality is to guide visual search for salient environmental items, whether these items are places of safety, a predator or food. In primates, visual search for salient environmental targets is conducted in either a parallel or serial mode (Itti and Koch 2001). The parallel mode guides attentional processes when the target object is distinct from surrounding distractor objects. Reaction time for detecting the target is very short in the parallel mode and is not lengthened by increasing the number of distractor objects. In this mode, the target is said to "pop-out" from the background distractors. Attentional processes are guided by the serial mode when the distractor items are similar to the target item. Increasing the number of distractors increases reaction time and no pop-out occurs. In primates, neocortical areas are associated with these search modes and consequent action selection (Bichot and Schall 2002; Li 2016).

Ben-Tov et al. (2015) have demonstrated both parallel and serial visual search modes in the archer fish and have found neural correlates of these processes in the optic tectum. Archer fish are able to prey on insects by hitting them with water forced from their specialized mouths. The insect is the salient object and the fish executes a visual search to locate it. Ben-Tov et al. used small rectangular bars as targets and established that the reaction time for archer fish to shoot a bar moving either faster than, or in the opposite direction from, distractor bars did not change as the number of distractors increased from 4 to 8. That is, the fish demonstrated the pop-out effect characteristic of the parallel mode of visual search. When the size of the bar was salient, reaction times for target selection 
increased as the number of distractors increased, indicating that the serial mode was being used.

Ben-Tov et al. identified neural correlates of pop-out in the tectum of archer fish. Discharge rates of tectal neurons correlated with characteristics of the selected target. "Speed-contrast" neurons fired at higher than baseline rates only when the speed of the target was salient while "direction-contrast" neurons fired at higher rates only when the target direction was salient. They also found "both-contrast "neurons that increased their discharge rates under either saliency condition.

Ben-Tov et al. also conducted an experiment in which the target was defined by a combination of speed and direction. Compared to selection rates for a single target feature, a target differentiated by both features was significantly more likely the be selected. When neurophysiological responses were investigated, Ben-Tov et al. found that some of the neurons that increased their firing rate to a single target increased the rate significantly more in the presence of the additive target.

In sum, archer fishes use the same attentional modes used by primates to construct a neural map of salient stimuli from a pre-attentional isomorphic neural map of the visual world. Both the isomorphic and salient neural structures are located in the tectum. The maps are dynamic and include neuronal circuits capable of associating two distinct characteristics of a visual stimulus (speed and direction of movement) to effectively drive a behavioral response. This capability may be interpreted as representing a simple form of sensory binding.

\subsection{Summary}

Several criteria have been suggested for a brain structure to qualify as a substrate of sentience (e.g., Crick and Koch 1990; 2003; G. Edelman 1989; Feinberg and Mallatt 2016; Seth et al. 2005). Each of these is a criterion for sentience, not sentience itself. One criterion is complexity of neural architecture and connectivity. The tectum meets this criterion. Two other criteria are isomorphic representation of sensory input and segregation of the sensory modalities. Isomorphic sensory maps are produced in the tectum. Additionally, the neural representation of each sensory modality is segregated from the others within the tectum. Another criterion is the presence of neural mechanisms for selective attention. The tectum has these mechanisms. The ability to merge, or bind, sensory input into a coherent image which can be used to direct motor output is also included. The additive effects of two distinct characteristics of a visual stimulus suggest that the tectum has this capacity. From this analysis, it is reasonable to hypothesize that the tectum is at least a part of the physical substrate of sentience in fishes.

Critics of this hypothesis are likely to insist that sentience requires structures that are homologous to the mammalian neocortex and thalamus and to maintain that the tectum and its interconnections failed to meet this requirement (e.g., Key 2015, 2016a, b; Rose 2002, 2007; Rose et al. 2012). It is also likely that critics would explain the ability of archer fish to discriminate between targets and distractors as some combination of reflex behavior and implicit discrimination learning. I admit there is room for such an argument. However, an explanation of the results of an experiment by Schuster et al. (2006) requires more than invoking implicit discrimination learning. 
Although moving targets are salient for archer fish, the ability to hit one reliably takes practice. Schuster et al (2006) trained archer fish to reliably hit a target $60 \mathrm{~cm}$ above the water traveling at $60 \mathrm{~mm} / \mathrm{s}$. As with the experiment by Ben-Tov et al. (2015), these results can be explained in behavioristic terms. However, the results of the second part of the experiment by Schuster et al. does not admit of such a simple explanation. They found that a second group of fishes, who only observed another fish hitting a moving target, were able to hit the target with a high rate of accuracy on their first opportunity to do so. It is difficult to explain this observation without reference to the ability of the observers to form and store in memory a mental image of other fish successfully executing the task. This is an example of declarative memory, which requires conscious awareness (Cohen et al. 1997; Eichenbaum and Cohen 2014; Squire et al. 2015), and is, therefore, a marker for the presence of sentience.

The proposal that declarative memory is necessary for the ability of archer fish to learn from observation leads to my second thesis that the pallium is a necessary component of the neural substrate for sentience in fishes. In this I diverge somewhat from the theory proposed by Feinberg and Mallatt (2016). Those authors do include a role in memory processing for the pallium in their model but they do not grant the pallium any place in the generation of mental images. Rather, the pallium simply modulates motor commands issued by the tectum (Feinberg and Mallatt 2016, Kindle edition, location 2580). I argue below that the pallium has a more central role in the formation of mental images - and, hence, in sentience in fishes - than simple modulation of tectal processing.

\section{SENTIENCE IN FISHES: PALLIAL ANATOMY}

\subsection{Overview of Sensory-Specific Connections}

The teleost pallium receives a variety of modality-specific sensory inputs (Giassi et al. 2012b; Ito and Yamamoto 2009; Northcutt 2006; Yamamoto and Ito 2008). As in mammals, all sensory modalities in fishes, other than olfaction, reach the pallium through a subpallial relay. Unlike mammals, the primary sensory relay is not the thalamus. The thalamus does contribute input to the teleost pallium (Echteler and Saidel 1981; Ito et al. 1986), but the diencephalic preglomerular complex (PgC; Figure 1B) - a component of what Mueller (2012) named the "wider thalamus" - is the principal source of its monosynaptic sensory input (Demski 2013; Giassi et al. 2012b; Mueller 2012; Northcutt 2006; Yamamoto and Ito 2008). The PgC receives topographically organized input from the tectum (Giassi et al. 2012a; Northcutt 2006) and its output to the pallium maintains modality segregation. Recognizing this, Ito and Yamamoto (2009) concluded that: "Ascending pathways mediated by the preglomerular complex enumerated above exhibit a considerable degree of modality-specific organization similarly to mammalian thalamocortical pathways" (p. 117). For example, visual input terminates most heavily in the dorsal lateral pallium (DLd/DLv in Figure 1). Indeed, the DLd has been proposed as the visual pallium for many teleosts (Demski 2013; Saidel et al. 2001). Cell clusters in different parts of the DM receive auditory, gustatory, and lateral line input (Demski 2013; Northcutt 2006; Prechtl et al. 2008). In some species, the DD receives some sensory input, but its major connections are with the other pallial divisions.

The DC receives comparatively little subpallial input but has reciprocal connections with other pallial divisions and is the major source of pallial output to the tectum, the PgC, and numerous other subpallial sensory-motor structures (Echteler and Saidel 1981; Giassi et 
al. 2011; Giassi et al. 2012b, c; Ito et al. 1986; Murakami et al. 1983). Therefore, the large neurons in the DC can affect motor programs or modulate sensory input to other pallial divisions through its connections to the diencephalic and midbrain motor and sensory processing sites.

\subsection{Non-Specific, Modulatory Pallial Inputs}

In addition to the qualities associated with sensory input from the environment, sentience includes subjective feelings associated with motivational and affective states such as hunger, thirst and fear. These states are supported not by sensory-specific input from subcortical structures, but by subcortical input that terminates throughout the cortex (Purvis et al. 2011). In mammals, these systems are associated with the cholinergic, dopaminergic, GABAergic, serotonergic, and noradrenergic neurotransmitter systems. The same neurotransmitter systems are found in fishes (Echteler and Saidel 1981; Giassi et al. 2012b, c; Giraldez-Perez et al. 2013; Mueller and Guo 2009; Murakami et al. 1983; Schweitzer et al. 2012). The presence of dopaminergic and serotonergic input suggests that motivational and affectual systems found in mammals also exist in fishes. These neurotransmitters are involved in guiding approach and avoidance behaviors (e.g., Dayan 2012). Feinberg and Mallatt (2016) rightly include the feeling states associated with these behaviors in what they call sensory consciousness and what I am calling sentience. The existence of these neurotransmitter systems in fishes provides additional support for sentience in teleosts.

Additionally, cholinergic, noradrenergic and serotonergic afferents to the cortex affect memory, attentional processes, and states of consciousness (e.g., awake or asleep, dream sleep or non-dream sleep) in mammals (Richerson et al. 2012). The presence of widespread input containing these neurotransmitters from subpallial structures, particularly the midbrain and hypothalamus, to the pallium suggests the existence of common modulatory mechanisms for these functions in fishes and mammals.

\subsection{Excitatory and Inhibitory Connections of the Pallial Divisions}

Research from Leonard Maler's laboratory at the University of Ottawa (Elliot et al., 2017; Giassi et al. 2012 a, b, c; Trinh et al. 2015) exploring the pallium of two species of weakly electric knifefish has confirmed the gross pattern of intrapallial connections observed in other teleost species (Echteler and Saidel 1981; Ito and Yamamoto, 2009; Northcutt, 2006), and has added important details. Excitatory neurons are required for positive feedforward and feedback control of local circuits. Inhibitory neurons are necessary for temporal stabilization and spatial sharpening of activity within these circuits.

Using immunocytochemical markers and localized injections of neurotracers, Giassi et al. (2012b, c) described the circuitry created by excitatory glutaminergic neurons. The DL has reciprocal excitatory connections to the DD, thus permitting feedforward/feedback excitation between the DL and DD. The DC receives excitatory glutaminergic input from the DL. Similar to what has been found in other species, the knifefish DC is the principal source of excitatory pallial output to diencephalic, midbrain and hindbrain targets, each of which returns excitatory input to the DL. These three regions of the fish pallium therefor have circuits that can support reentrant processing, one of the proposed requirements for a 
neurobiological substrate of sentience (e.g., Crick and Koch 2003; G. Edelman 1989; G. Edelman et al. 2011).

Mueller and Guo (2009) observed presumptive inhibitory GABAergic neurons in the DL, DD, DM and DC in zebrafish. Giassi et al. (2012a, c) confirmed this observation in knifefish. Giassi et al. (2012c) also observed rich intrinsic GABAergic plexuses and numerous GABAergic terminals, particularly in the DL. The source of some of this GABAergic innervation is the telencephalic subpallium (Elliot et al. 2017; Giassi et al. 2012c; VT in Figure 1B) which, in turn, receives excitatory glutaminergic input from the DM (Gaissi et al. 2012b, c). Whether the source is intrinsic or extrinsic, GABAergic terminals within the DL, DM and DD modulate the activity of excitatory glutaminergic neurons (R. Vargas et al. 2012).

\subsection{Pallial Layers and Cryptic Columns in the DL}

Giassi et al. (2012c) investigated the extrinsic connections of the DL and the other pallial divisions of the knifefish. In order to study the intrinsic connections of the DL, Trinh et al. (2015) incubated slices of the pallia from knifefish in nutritive media. They located the DL in the slice and used a microscope to guide injections of axonal tracers into discrete parts of it. Analysis of the resulting data indicated that the trajectory of the intrinsic axons arising from some of the large neurons within the DL separate it into $\sim 60-\mu \mathrm{m}$-thick lamina along its horizontal axis. Axons from other large neurons have projections extending 100 to $150 \mu \mathrm{m}$. These projections delineate columns along the vertical axis. Each column connects reciprocally to adjacent columns creating local recurrent networks throughout the DL. Thus, the DL of the knifefish pallium exhibits both a layered and a columnar organization.

Such a neuronal organization is characteristic of the mammalian cortex, but Trinh et al. (2015) emphasize that the columns observed in knifefish are not structurally discrete in the same way as columns in regions of the mammalian neocortex, such as the somatosensory cortex. Rather, they resemble the overlapping cryptic ocular dominance columns found in the visual cortex (e.g., Kaskan et al. 2007). Cryptic columnar organization allows small changes in input to one column to cause a slight shift in neuronal activity in overlapping columns, thereby allowing spatiotemporal integration of sensory input and binding.

\subsection{Fish Pallial Anatomy: Summary}

The research reviewed above indicates that the fish pallium has reciprocal connections with subcortical structures that provide it with both specific sensory and nonspecific modulatory input. The specific sensory input to the pallium arises primarily from the $\mathrm{PgC}$ and is analogous to the reentrant network between the thalamus and cortex in mammals which has been proposed to correlate with conscious experience of environmental stimuli. The non-specific input comes from ventral telencephalic, diencephalic and brainstem nuclei, and contains neurotransmitters associated with affective and motivational states in mammals. My conclusion is that the teleost pallium has the neuroanatomical complexity necessary to contribute to sentience. In the next section, I will give evidence that the pallium also exhibits neurophysiological markers of sentience. 


\section{SENTIENCE IN FISHES: PALLIAL NEUROPHYSIOLOGY}

\subsection{Pallial Rhythmic Electrical Activity}

There are few relevant neurophysiological experiments, and they were not specifically designed to evaluate the pallium for correlates of sentience. However, their results suggest the fish pallium exhibits generalized electrophysiological responses correlated with several criteria of sentience in mammals. For example, recordings of the electroencephalograms from the skulls of Atlantic salmon (E. Lambooji et al., 2010), African catfish (E. Lambooji et al. 2006) and the turbot (B. Lambooji et al. 2015) demonstrated that the pallium of the fish generates electrical activity in the delta $(0.5-4 \mathrm{~Hz})$, theta $(4-8 \mathrm{~Hz})$, alpha $(8-14 \mathrm{~Hz})$, beta (14-30 Hz) and gamma (30 Hz and higher) bandwidths. The same spectrum of EEG frequencies is generated by the mammalian cortex and correlates with levels of arousal and, at the gamma frequency, with attentional processes and possibly with sensory binding. (Baars et al. 2013; Crick and Koch 1990; 2003; Edelman 2003; Orpwood 2013; Tononi and Edelman 1998). In addition to generalized electrophysiological responses similar to those found in the mammalian cortex, the teleost pallium shows modality-specific, sense-evoked responses (Prechtl et al. 2008; Elliot and Maier 2015).

\subsection{Sensory-Evoked Activity}

Prechtl et al. (1998) recorded evoked action potentials from the pallial neurons of weakly electric elephant nose fish in response to auditory, visual, mechanical (water movement), lateral line and electrical field stimulation. The electrical field stimulation was not noxious, but intended to mimic stimulation produced by the fish itself, or by conspecifics. In accord with the anatomical data described above, responses to visual stimuli were observed predominantly in the lateral pallium. Responses to electrical stimuli also occurred more laterally in the pallium, but were clustered toward its posterior (toward the tail) pole. Mechanical-stimuli-evoked responses mostly from neurons located ventromedial to the area where responses to electrical stimuli predominated and auditory-evoked responses were predominantly found in the anterior medial pallium. It is interesting that Prechtl et al. also observed that the sensory stimuli used in their study produced field potentials that oscillated in bandwidths from 15 to $55 \mathrm{~Hz}$. The higher end of these bandwidths corresponds to the gamma frequency proposed, as noted previously, to be the neurobiological signature of attentional processes and sensory binding.

I indicated above that the primary interconnectivity of the DD is with other pallial divisions. Using electric brown ghost knifefish, Elliot and Maler (2015) made extracellular and patch-clamp recordings from DD neurons in response to electrosensory or acoustic stimulation. Extracellular recording revealed that DD neurons exhibited sustained discharge to electrosensory stimulation. It is interesting that the onset latency for DD neurons to respond to electrosensory stimulation was substantially longer than that found for medial pallial neurons to respond in the study by Prechtl et al. (1998). This finding is compatible with the anatomical data that indicate the DD does not receive significant direct sensory input, but adds further processing to sensory input to the DL and DM. Patch-clamp recordings 
indicated that the membrane potential for DD neurons went from the persistent "down" state of approximately $-70 \mathrm{mV}$ to an "up" state of approximately $-45 \mathrm{mV}$ in response to electrosensory stimulation. The shift to a smaller negative membrane voltage indicates an increase in neuronal excitability, and these responses correlated with the frequency of extracellular spiking. Acoustic stimulation produced similar effects. In interpreting these results, Elliot and Maler (2015) hypothesized that "Up states are induced by complex and variable pallial network activity that intervenes between sensory input and DD cells" (p. 2075). The results of this experiment suggest that the DD may be involved in longer-term cognitive processing of input to other pallial divisions and can be taken as support for the proposal that the DD serves as an association region, thereby expanding the regional complexity of the pallium.

\subsection{Fish Pallial Neurophysiology: Summary}

Neurophysiological studies show that neurons in the fish pallium generate the same spectrum of EEG frequencies and waveforms observed in mammals. Pallial neurons also respond to sensory stimulation with specific evoked responses that show some segregation by sensory modality. Sensory stimulation also evokes EEG activity in the gamma bandwidth, a presumed correlate of attentional processes and sensory binding. Additionally, electrophysiological data support the hypothesis, generated from anatomical data, that a part of the pallium, the DD, possibly serves an associative function. These electrophysiological data are consistent with the hypothesis that the fish pallium contributes to the production of sentience in fishes.

\section{THE PALLIUM AND BEHAVIORAL MARKERS OF SENTIENCE}

The purpose of this section is to discuss experiments that link behavior of fishes to both the pallium and sentience. I will not discuss the substantial body of behavioral research that is supportive of my thesis that fishes are sentient because most of it was not designed to evaluate the role of the pallium in behavior. Additionally, much of it has been reviewed in recent publications (Allen 2013; Balcombe 2016; Braithwaite 2010; Brown 2014, 2016; Brown et al. 2011; Sneddon 2015).

Two general categories of behavior have dominated the published literature concerned with the behavioral functions of the fish pallium. The reason for this dominance stems from the anatomical, developmental, and molecular research that points to the medial pallium (DM - DMd and DMv in Figure 1B) of fishes as a homolog to the mammalian amygdala, and to the lateral pallium (DL - DLd/DLv) as a homolog to the mammalian hippocampus (Ganz et al. 2015; Harvey-Girard et al. 2012; Nieuwenhuys and Meek 1990; Northcutt 2006). These homologies led to the hypothesis that lesions of the DM or DL would have the same behavioral effects as lesions of the amygdala or hippocampus in mammals. Research generated primarily by researchers at the Universidad de Sevilla has largely supported this hypothesis (Portovella et al 2004a, b; Vargas et al. 2006; 2012).

\subsection{Avoidance Behavior and the Pallium}


As indicated earlier, I follow Allen and Trestman (2016) and define sentience broadly as the ability to have any subjective experience. This definition differs from that of Feinberg and Mallatt (2016) who regard sentience as the affective component of sensory consciousness. Despite this definitional disagreement, I agree with their requirement that "for an animal to be 'sentient' it must be capable of experiencing an affective state" (Feinberg and Mallatt 2016, Kindle location 3055).

Lesions of the DM impair learned behaviors motivated by aversive stimuli in the same way that destruction of the amygdala does in mammals (Davis 1992). For example, Portavella et al. (2004a, b) assessed the effects of either DM or DL lesions on the ability of goldfish to learn a shuttle-box avoidance task. A shuttle box has two compartments. The fish had to learn to swim from one box to the other in response to presentation of a colored light (the conditioned stimulus, CS) in order to avoid electrical shock (the unconditioned stimulus, US). Portavella et al. found that DM lesions had no effect on escape from electrical shock, but significantly impaired learning of the avoidance response to the CS. DL lesions had no effect.

These results support the hypotheses that integrity of the DM is necessary for successful performance of a learned, aversively-motivated behavior and that it is a homolog of the amygdala. However, whether sentience is required to explain the acquisition of shuttlebox avoidance can be questioned. The answer to this question depends on interpretation of the two-process theory usually used to explain shuttle-box avoidance learning (Mowrer 1960). The first process is classical conditioning. The CS produces a conditioned emotional response after repeated association with the innate aversive emotional response produced by the US. The second process is operant conditioning. On one interpretation, the innate and conditioned emotional responses are equated to experience of fear. Reinforcement occurs when the avoidance response reduces fear (Mowrer 1960). Several publications describing a variety of other procedures to assess avoidance behavior in intact members of several species of fish support this view (e.g., Braithwaite 2010; Braithwaite and Boulcott 2007). If fear is considered to be a consciously experienced state, then the ability of fishes to learn shuttlebox avoidance supports the hypothesis that they are sentient. Under this interpretation, the DM is part of a distributed neural system that generates the feeling of fear. Subpallial structures comprise the core of this system, and, in conjunction with the DM, participate in elaboration of the negative affectual component of sentience in fishes.

\subsection{Declarative Memory and the Pallium}

Declarative memory in humans and other mammals is associated with availability for conscious recollection and provides flexible guidance to behavior in different contexts. Behaviors that require relational learning among stimuli distributed either over time or in space are considered to be exemplars of declarative memory. Transitive inference (TI) provides an excellent example (Cohen et al. 1997; Eichenbaum and Cohen 2014). TI is the ability to infer a relationship between items that have not been previously directly compared. First observing that $\mathrm{A}<\mathrm{B}, \mathrm{B}<\mathrm{C}$, and $\mathrm{C}<\mathrm{D}$, and then deducing that $\mathrm{A}<\mathrm{D}$ is an example of TI. In humans TI requires conscious awareness of the relationships (Smith and Squire 2005). Thus, the presence of TI in a non-human species can be taken as an indication that the species is sentient.

Grosenick et al. (2007) demonstrated that male cichlid fish (Astatotiliapia burtoni) exhibit TI in an observational learning situation. Male A. burtoni inevitably fight for territory. 
A bystander male (BM) was placed in the center of an arena surrounded by five small compartments (A through E) with transparent walls. Each compartment housed a combatant fish (CF). CF B was introduced into CF A's compartment, then CF C into CF B's, and so on. Each invader lost the ensuing fight. For example, $\mathrm{CF} A$ beat $\mathrm{CF} B$ and $\mathrm{CF} D$ beat $\mathrm{CF}$ E. CF A and CF E were then placed in separate transparent chambers and the time the BM spent near each fish was recorded. This was repeated for CF B and CF D. Although CF A had not fought with CF E, nor $\mathrm{CF} B$ with $\mathrm{CF}$ D, the BMs consistently spent more time in the vicinity of the losers (B and E) than they did in the vicinity of winners. This is a clear indication of TI and supports the hypothesis that fish are sentient.

Destruction of the hippocampus significantly impairs behaviors associated with declarative memory (Eichenbaum and Cohen 2014; Squire et al. 2015) including TI (Smith and Squire 2005). Because the DL of fishes is considered to be the homolog of the hippocampus, lesions of the DL should disrupt behaviors associated with declarative memory in fishes. The effects of DL lesions on TI in fishes have not been demonstrated, although it is a testable hypothesis that DL lesions would impair TI in archer fishes. However, other behaviors requiring relational learning have been identified in fishes (Gerlai 2017), and the effect of DL lesions on some of these has been demonstrated.

Declarative memory is distinguished from procedural or implicit memory which is unconscious and is characterized by inflexible stimulus response associations. Classical conditioning is regarded as a characteristic example of procedural memory. It is dependent upon the integrity of the cerebellum regardless of the temporal relationship between the CS and the US (Christian and Thompson 2003). The hippocampus is not required for procedural memory, including classical conditioning, except under a specific experimental design known as "trace" conditioning. In the trace procedure, the US is turned on at some time after the CS been turned off. Thus, the term "trace" refers to the assumption that there must be some trace of the CS remaining to relate it to the US across the temporal gap between the offset of the CS and the onset of the US. This procedure differs from the "delay" procedure in which the US comes on while the CS is still present. Hippocampal destruction in humans and other mammals has no effect on conditioning in the delay procedure (Christian and Thompson 2003). Nor does destruction of the DL in the goldfish impair classical conditioning when the delay procedure is used (Gómez et al. 2016; Rodríguez-Expósito et al. 2017).

However, hippocampal destruction does impair acquisition of classical conditioning when the trace procedure is employed in both mammals (Weiss et al. 2015) and goldfish (Gómez et al. 2016; Rodríguez-Expósito 2017). These results do not mean that the cerebellum is not important in trace conditioning, as cerebellar destruction impairs trace conditioning in both mammals and fish. They are, however, interpreted to indicate that the hippocampus (or DL in fishes) functions in concert with the cerebellum in trace conditioning to enable declarative memory - and thus conscious awareness - to form a conscious image from memory to relate the CS and US across the temporal gap.

The same effect has been reported for shuttle-box avoidance learning by Portavella et al. (2004a). As described above, while DM lesions impaired shuttle-box avoidance learning, DL lesions had no effect when the delay procedure was used. However, when a trace procedure in which there was a five-second delay between the offset of the CS in the onset of the US was used, both DM and DL lesions impaired shuttle-box avoidance learning. These results are compatible with research in humans indicating that trace conditioning involves 
conscious awareness (Clark and Squire 1998) and hence give some support to the hypothesis that fish are sentient.

In addition to TI, Eichenbaum (2000) considers allocentric spatial learning to be a clear indication of the presence of declarative memory in animals. Allocentric spatial learning refers to the ability of a person or animal to encode and organize the memory system for spatial information based on the physical relationships of objects as part of a distant scene independent of the subject's position relative to those objects. A large number of teleost species demonstrate allocentric spatial learning (e.g., Brown 2014; Durán et al. 2010; Creson et al. 2003; White and Brown 2015). The mammalian hippocampus is associated with allocentric spatial processing (Nadel 1991). The following evidence indicates that the DL is associated with spatial learning in fish.

Hippocampal neurons in rats show place-related increases in the firing rate, and hippocampal lesions impair allocentric spatial learning in rats (Nadel 1991). DL neurons in freely swimming goldfish and cichlid fish show place-related increases in the firing rate (Canfield and Mizumori 2004), and Uceda et al. (2015) observed spatial-learning-related increases in metabolic activity in the goldfish ventral DLv. Furthermore, a series of experiments from the Seville group indicate that lesions of the entire DL (e.g., Durán et al. 2010; J. Vargas et al. 2006), or just to the DLv (Bingman et al. 2017), impair allocentric spatial learning in goldfish. DM lesions, on the other hand, have no effect on allocentric spatial learning (Durán et al. 2010; J. Vargas et al. 2006).

\subsection{The Pallium and Behavior: Summary}

In this section I have described the results of experiments which indicate a double dissociation between the behavioral effects of DM and DL lesions. DL lesions impair behavior only when the task demands that a relationship among stimuli be maintained across time or in space. I argue that this implicates the DL in declarative memory which by general consensus implies conscious awareness. DM lesions, on the other hand, impair behaviors generally associated with procedural memory which does not require conscious awareness. However, even here, the DM may be involved in the affective component of sentience if the two-process theory of shuttle-box learning is interpreted to involve a subjective sense of fear. Particularly for the DM, the function of these pallial structures in the modulation of behavior is part of a network that includes core subpallial structures. However, I argue that the DL plays an important role in the generation of mental images, and thereby sentience, when declarative memory is required for successful execution of motor programs that are organized in brainstem structures.

\section{CONCLUSION}

In this target article, I have argued that fish are sentient. As indicated above, this argument has been cogently made by others based on the complexity of brainstem circuitry (e.g., Feinberg and Mallatt 2013, 2016; Merker 2007), and the flexibility and complexity of the behavior of fishes (e.g., Balcombe 2016; Braithwaite 2010; Brown 2014; Brown et al. 2011). I have also argued that the intrinsic neuroanatomical organization and extrinsic connections of the pallium, particularly with the $\mathrm{PgC}$ and the tectum, are complex enough to be at least weakly analogous to the circuitry of the cortex and thalamus assumed by some to 
underlie sentience in mammals. Neurophysiological and behavioral data further support the hypothesis that fish have the capacity for sentience.

Based on the evidence reviewed in this paper, I suggest that the pallium is an important part of the hierarchical network proposed by Feinberg and Mallatt (2016) to underlie sentience in fishes. The tectum is at the core of this network. The tectum receives segregated sensory input and has the local and global reentrant neural circuitry needed to amplify and process this input. Segregation of the sensory modalities is maintained through the PgC to the pallium. The pallium also receives input from subpallial structures involved in placing a positive or negative valence on this input. These inputs are then integrated by various divisions of the pallium. Particularly in the case of the DL and declarative memory, the result of this integration is the formation of mental images that permit relational interactions among stimuli and flexible regulation of behaviors organized in the brainstem.

In her book Animal Minds, Andrews (2015) makes the point that, "Members of the human species have human minds, and if members of other species have minds, they will have species-specific minds of their own" (p. 4). It is safe to say the same about those processes of the mind of fishes I call sentience. Fish sentience differs from human sentience, and what it feels like is as unknowable to us as what it feels like to be a bat. However, just as Nagel (1974) found it reasonable for there to be something it feels like to be a bat, I think that it is reasonable to adduce from the existing evidence that there is something it feels like to be a fish.

\section{Acknowledgements}

I thank Dr. Hugh Lafollette and Dr. Ana Giassi for helping me obtain copies of several of the publications referenced in this paper and for their valuable comments on its draft versions. I also acknowledge the helpful comments from the reviewers of the initial submission.

Call for Commentary: Animal Sentience publishes Open Peer Commentary on all accepted target articles. Target articles are peer-reviewed. Commentaries are editorially reviewed. There are submitted commentaries as well as invited commentaries. Commentaries appear as soon as they have been reviewed, revised and accepted. Target article authors may respond to their commentaries individually or in a joint response to multiple commentaries.

Instructions: http://animalstudiesrepository.org/animsent/guidelines.html

\section{References}

Allen, C. (2013). Fish cognition and consciousness. Journal of Agriculture and Environmental Ethics, 26, 25-39.

Allen, C. and Trestman, M. (2016). Animal consciousness. In E. N. Zalta (Ed.), The Stanford encyclopedia of philosophy (Winter Edition). Retrieved from https://plato.stanford.edu/archives/win2016/entries/consciousness-animal/.

Andrews, K. (2015). Animal minds: an introduction to the philosophy of animal cognition. New York, NY: Routledge.

Baars, B. J. (1997). Some essential differences between consciousness and attention, perception, and working memory. Consciousness and Cognition, 6, 363-367. 
Baars, B. J., Franklin, S. and Ramsoy, T. Z. (2013). Global workspace dynamics: cortical "binding and propagation" enables conscious contents. Frontiers in Psychology, 4, 200.

Balcombe, J. (2016). In praise of fishes: précis of What a fish knows. Animal Sentience 8(1).

Barker A. J. and Baier, H. (2015). Sensorimotor decision making in the zebrafish tectum. Current Biology, 25, 2804-2814.

Ben-Tov, M., Donchin, O., Ben-Shahar, O. and Segev, R. (2015). Pop-out in visual search of moving targets in the archer fish. Nature Communications, 6, 6476.

Bichot, N. P. and Schall, J. D. (2002). Priming in macaque frontal cortex during popout visual search: feature-based facilitation and location-based inhibition of return. Journal of Neuroscience, 22, 4675-4685.

Bingman, V.P., Rodríguez, F. and Salas, C. (2017). The hippocampus of nonmammalian vertebrates. In J. Kaas (Ed.), Evolution of nervous systems (2nd ed., Vol. 1) (pp. 479-489). Oxford, UK: Elsevier.

Braithwaite, V. A. (2010). Do fish feel pain? Oxford, UK: Oxford University Press.

Braithwaite, V. A. and Boulcott, P. (2007). Pain perception, aversion and fear in fish. Diseases of Aquatic Organisms, 75, 131-138.

Brown, C. (2014). Fish intelligence, sentience and ethics. Animal Cognition, 18, 1-17.

Brown, C. (2016). Comparative evolutionary approach to pain perception in fishes. Animal Sentience 3(5).

Brown, C., Laland, K. and Krause, J. (2011). Fish cognition and behavior (2nd ed.) Cambridge, UK: Wiley-Blackwell.

Cabanac, M., Cabanac, J. and Parent A. (2009). The emergence of consciousness in phylogeny. Behavioural Brain Research, 198, 267-272.

Canfield, J. G. and Mizumori, S. J. Y. (2004). Methods for chronic neural recording in the telencephalon of freely behaving fish. Journal of Neuroscience Methods, 133, 127-134.

Christian, K. M. and Thompson, R. F. (2003). Neural substrates of eyeblink conditioning: Acquisition and retention. Learning \& Memory, 10, 427-455.

Clark, R. E. and Squire, L. R. (1998). Classical conditioning and brain systems: the role of awareness. Science, 280, 77-81.

Cohen, N. J., Poldrack, R. A. and Eichenbaum, H. (1997). Memory for items and memory for relations in the procedural/declarative memory framework. Memory, 5, 131-178.

Creson, T. K., Woodruff, M. L., Ferslew, K. E., Rasch, E. M. and Monaco, P. J. (2003). Doseresponse effects of chronic lithium regimen on spatial memory in the black molly fish. Pharmacology, Biochemistry and Behavior, 75, 35-47.

Crick, F. and Koch, C. (1990). Towards a neurobiological theory of consciousness. Seminars in the Neurosciences, 2, 263-275.

Crick, F. and Koch, C. (2003). A framework for consciousness. Nature Neuroscience, 6, 119-126.

Damasio, A. R. (2010). Self comes to mind: constructing the conscious mind. New York, NY: Pantheon Books.

Davis, M. (1992) The role of the amygdala in fear and anxiety. Annual Review of Neuroscience, 15, 353-375.

Dayan, P. (2012). Instrumental vigour in punishment and reward. European Journal of Neuroscience, 35, 1152-1168.

Del Bene, F., Wyart, C., Robles, E., Tran, A., Looger, L., Scott, E. K., Isacoff, E. Y. and Baier, H. (2010). Filtering of visual information in the tectum by an identified neural circuit. 
Science, 330, 669-673. Demski, L. S. (2013). The pallium and mind/behavior relationships in teleost fishes. Brain Behavior and Evolution, 82, 31-44.

Durán, E., Ocaña, F. M., Broglio, C., Rodríguez, F. and Salas, C. (2010). Lateral but not medial telencephalic pallium ablation impairs the use of goldfish spatial allocentric strategies in a "hole-board" task. Behavioural Brain Research, 214, 480-487.

Echteler, S. M. and Saidel, W. M. (1981). Forebrain connections in the goldfish support telencephalic homologies with land vertebrates. Science, 212, 683-685.

Edelman, D. B., Baars, B. J. and Seth, A. (2005). Identifying hallmarks of consciousness in non-mammalian species. Consciousness and Cognition, 14, 169-187.

Edelman, G. M. (1989). The remembered present: a biological theory of consciousness. New York, NY: Basic Books.

Edelman, G. M., Gally, J. A. and Baars, B. J. (2011). Biology of consciousness. Frontiers in Psychology, 2, 4.

Eichenbaum, H. (2000). A cortical-hippocampal system for declarative memory. Nature Reviews Neuroscience, 1, 41-50.

Eichenbaum, H. and Cohen, N. J. (2014). Can we reconcile the declarative memory and spatial navigation views on hippocampal function? Neuron, 83, 764-770.

Elliott, S. B., Harvey-Girard, E., Giassi, A. C. C. and Maler, L. (2017). Hippocampal-like circuitry in the pallium of an electric fish: possible substrates for recursive pattern separation and completion. Journal of Comparative Neurology, 525, 8-46.

Elliott, S., and Maler, L. (2015). Stimulus-induced up states in the dorsal pallium of a weakly electric fish. Journal of Neurophysiology, 114, 2071-2076.Feinberg, T. E. and Mallatt, J. (2013). The evolutionary and genetic origins of consciousness in the Cambrian Period over 500 million years ago. Frontiers in Psychology, 4, 00667.

Feinberg, T. E. and Mallatt, J. M. (2016). The ancient origins of consciousness: how the brain created experience. Cambridge, MA: MIT Press.

Ganz, J., Kroehne, V., Freudenreich, D., Machate, A., Geffarth, M., Braasch, I., Kaslin, J. and Brand, M. (2015). Subdivisions of the adult zebrafish pallium based on molecular marker analysis. F1000Research, 3, 308.

Gerlai, R. (2017, in press). Zebrafish and relational memory: could a simple fish be useful for the analysis of biological mechanisms of complex vertebrate learning? Behavioural Processes, http://dx.doi.org/10.1016/j.beproc.2017.01.016.

Giassi, A. C. C., Duarte, T. T., Ellis, W. and Maler, L. (2012b). Organization of the gymnotiform fish pallium in relation to learning and memory: II. Extrinsic connections. Journal of Comparative Neurology, 520, 3338-3368.

Giassi, A. C. C., Ellis, W. and Maler, L. (2012c). Organization of the gymnotiform fish pallium in relation to learning and memory: III. Intrinsic connections. Journal of Comparative Neurology, 520, 3369-3394.

Giassi, A. C. C., Harvey-Girard, E., Valsamis, B. and Maler, L. (2012a). Organization of the gymnotiform fish pallium in relation to learning and memory: I. Cytoarchitectonics and cellular morphology. Journal of Comparative Neurology, 520, 3314-3337.

Giassi, A. C. C., Maler, L., Moreira, J. E. and Hoffmann, A. (2011). Glomerular nucleus of the weakly electric fish, gymnotus sp.: cytoarchitecture, histochemistry, and fiber connections - insights from neuroanatomy to evolution and behavior. Journal of Comparative Neurology, 519, 1658-1676. Giraldez-Perez, R. M., Gaytan, S. P. and Pasaro, 
R. (2013). Cholinergic and nitrergic neuronal networks in the goldfish telencephalon. Acta Neurobiologiae Experimentalis, 73, 338-353.

Gómez, A., Rodríguez-Expósito, B., Durán, E., Martín-Monzón, I., Broglio, C., Salas, C. and Rodríguez, F. (2016). Relational and procedural memory systems in the goldfish brain revealed by trace and delay eyeblink-like conditioning. Physiology \& Behavior, 167, 332340.

Grosenick, L., Clement, T. S. and Fernald, R. D. (2007). Fish can infer social rank by observation alone. Nature, 445, 429-432.

Harvey-Girard, E., Giassi, A. C., Ellis, W. and Maler, L. (2012). Organization of the gymnotiform fish pallium in relation to learning and memory: IV. Expression of conserved transcription factors and implications for the evolution of dorsal telencephalon. Journal of Comparative Neurology, 520, 3395-3413.

Howe, P. D. L., Evans, K. K., Pedersini, R., Horowitz, T. S., Wolfe, J. M. and Cohen, M. A. (2009). Attention: selective attention and consciousness. In W. P. Banks (Ed.), Encyclopedia of consciousness, Vol. 1 (pp. 61-75). Oxford, UK: Elsevier.

Ito, H. and Yamamoto, N. (2009). Non-laminar cerebral cortex in teleost fishes? Biology Letters, 5, 117-121.

Ito, H., Murakami, T., Fukuoka, T. and Kishida, R. (1986). Thalamic fiber connections in a teleost (Sebastiscus marmoratus): visual somatosensory, octavolateral, and cerebellar relay region to the telencephalon. Journal of Comparative Neurology, 250, 215-227.

Itti, L. and Koch, C. (2001). Computational modelling of visual attention. Nature Reviews Neuroscience, 2, 194-203. Kardamakisa, A., Saitoh, K. and Grillner, S. (2015). Tectal microcircuit generating visual selection commands on gaze-controlling neurons. Proceedings of the National Academy of Sciences, USA, 112, E1956-E1965.

Kaskan, P. M., Lu, H. D., Dillenburger, B. C., Roe, A. W. and Kaas, J. H. (2007). Intrinsic-signal optical imaging reveals cryptic ocular dominance columns in primary visual cortex of New World owl monkeys. Frontiers in Neuroscience, 1, 67-75.

Key, B. (2015). Fish do not feel pain and its implications for understanding phenomenal consciousness. Biology and Philosophy, 30, 149-165.

Key, B. (2016a). Why fish do not feel pain. Animal Sentience 3(1).

Key, B. (2016b). Falsifying the null hypothesis that "fish do not feel pain". Animal Sentience 3(39).

Kinoshita, M., Ito, E., Urano, A., Ito, H. and Yamamoto, N. (2006). Periventricular efferent neurons in the optic tectum of rainbow trout. Journal of Comparative Neurology, 499, 546-564.

Lambooij, B., Bracke, M., Reimert, H., Foss, A., Imsland, A. and van de Vis, H. (2015). Electrophysiological and behavioural responses of turbot (Scophthalmus maximus) cooled in ice water. Physiology and Behavior, 149, 23-28.

Lambooij, E., Grimsbø, E., van de Vis, J. W., Reimert, H. G. M., Nortvedt, R. and Roth, B. (2010). Percussion and electrical stunning of Atlantic salmon (Salmo salar) after dewatering and subsequent effect on brain and heart activities. Aquaculture, 300, 107112.

Lambooij, E., Kloosterboer, R., Gerritzen, M., and Van de Vis, J. (2006). Assessment of electrical stunning in fresh water of African catfish (Clarias gariepinus) and chilling in ice water for loss of consciousness and sensibility. Aquaculture, 254, 388-395. 
Li, Z. (2016). From the optic tectum to the primary visual cortex: migration through evolution of the saliency map for exogenous attentional guidance. Current Opinion in Neurobiology, 40, 94-102.

Meek, J. (1983). Functional anatomy of the tectum mesencephali of the goldfish. An explorative analysis of the functional implications of the laminar structural organization of the tectum. Brain Research, 287, 247-297.

Merker, B. (2007). Consciousness without a cerebral cortex: a challenge for neuroscience and medicine. Behavioral and Brain Sciences, 30, 63-81.

Mowrer, O. H. (1960). Learning theory and behavior. New York, NY: John Wiley.

Mueller, T. (2012). What is the thalamus in zebrafish? Frontiers in Neuroscience, 64, 1.

Mueller, T. and Guo, S. (2009). The distribution of GAD67-mRNA in the adult zebrafish (teleost) forebrain reveals a prosomeric pattern and suggests previously unidentified homologies to tetrapods. Journal of Comparative Neurology, 516, 553-568.

Murakami, T., Morita, Y. and Ito, H. (1983). Extrinsic and intrinsic fiber connections of the telencephalon in a teleost, Sebastiscus marmoratus. Journal of Comparative Neurology, 216, 115-131.

Nadel, L. (1991). The hippocampus and space revisited. Hippocampus 1, 221-229.

Nagel, T. (1974). What is it like to be a bat? The Philosophical Review, 83, 435-450.

Nevin, L. M., Robles, E., Baier, H. and Scott, E. K. (2010). Focusing on optic tectum circuitry through the lens of genetics. BMC Biology, 8, 126.

Nieuwenhuys, R. and Meek, J. (1990). The telencephalon of actinopterygian fishes. In E. G. Jones and A. Peters (Eds.), Comparative structure and evolution of the cerebral cortex (pp. 31-73). New York, NY: Plenum.

Northcutt, R. G. (2006). Connections of the lateral and medial divisions of the goldfish telencephalic pallium. Journal of Comparative Neurology, 494, 903-943.

Orpwood, R. (2013). Qualia could arise from information processing in local cortical networks. Frontiers in Psychology, 4, 121.

Panksepp, J. (2005). Affective consciousness: core emotional feelings in animals and humans. Consciousness and Cognition, 14, 30-80.

Portavella, M., Torres, B. and Salas, C. (2004a). Avoidance response in goldfish: emotional and temporal involvement of medial and lateral telencephalic pallium. Journal of Neuroscience, 24, 2335-2342.

Portavella, M., Torres, B., Salas, C. and Papini, M. R. (2004b). Lesions of the medial pallium, but not of the lateral pallium, disrupt spaced-trial avoidance learning in goldfish (Carassius auratus). Neuroscience Letters, 362, 75-78.

Prechtl, J. C., von der Emde, G., Wolfart, J., Karamürsel, S., Akoev, G. N., Andrianov, Y. N. and Bullock, T. H. (1998). Sensory processing in the pallium of a mormyrid fish. Journal of Neuroscience, 18, 7381-7393.

Purvis, D., Augustine, G. J, Fitzpatrick, D., Hall, W. C., LaMantia, A-S. and White, L. E. (2011). Neuroscience (5th ed.). Sunderland, MA: Sinauer Associates.

Richerson, G. B., Aston-Jones, G. and Saper, C. B. (2012). The modulatory functions of the brain stem. In E. J. Kandel, J. H. Schwartz, T. M. Jessell, S. A. Siegelbaum and A. J. Hudspeth (Eds.), Principles of neural science (5th ed.) (pp. 1039-1055). New York, NY: McGraw Hill. 
Rodríguez-Expósito, B., Gómez, A., Martín-Monzón, I., Reiriz, M., Rodríguez, F. and Salas, C. (2017). Goldfish hippocampal pallium is essential to associate temporally discontiguous events. Neurobiology of Learning and Memory, 139, 128-134.

Rose, J. (2007). Anthropomorphism and 'mental welfare' of fishes. Diseases of Aquatic Organisms, 75, 139-154.

Rose, J. D. (2002). The neurobehavioral nature of fishes and the question of awareness and pain. Reviews in Fisheries Science, 10, 1-38.

Rose, J. D., Arlinghaus, R., Cooke, S. J., Diggles, B. K., Sawynok, W., Stevens, E. D. and Wynne, C. (2012). Can fish really feel pain? Fish and Fisheries, 15, 97-133.

Saidel, W. M., Marquez-Houston, K. and Butler, A. B. (2001). Identification of visual pallial telencephalon in the goldfish, Carassius auratus: a combined cytochrome oxidase and electrophysiological study. Brain Research, 919, 82-93.

Sato, T., Hamaoka, T., Aizawa, H., Hosoya, T. and Hitoshi Okamoto, H. (2007). Genetic singlecell mosaic analysis implicates ephrinB2 reverse signaling in projections from the posterior tectum to the hindbrain in zebrafish. The Journal of Neuroscience, 27, 52715279.

Schuster, S., Wo, S., Griebsch, M. and Klostermeier, I. (2006). Report animal cognition: how archer fish learn to down rapidly moving targets. Current Biology, 16, 378-383.

Schweitzer, J., Löhr, H., Filippi, A. and Drieve, W. (2012). Dopaminergic and noradrenergic circuit development in zebrafish. Devlopmental Neurobiology, 72, 256-268.

Seth, A. K., Baars, B. J. and Edelman, D. B. (2005). Criteria for consciousness in humans and other mammals. Consciousness and Cognition, 14, 119-139.

Smith, C. and Squire, L. R. (2005). Declarative memory, awareness, and transitive inference. Journal of Neuroscience, 25, 10138-10146.

Sneddon, L. U. (2015). Pain in aquatic animals. Journal of Experimental Biology, 218, $967-$ 976.

Squire, L. R. and Dede, A. J. O. (2015). Conscious and unconscious memory systems. Cold Spring Harbor Perspectives in Biology, 7, a021667.

Tononi, G. and Edelman, G. M. (1998). Consciousness and complexity. Science, 282, 18461851.

Tononi, G. and Koch, C. (2015). Consciousness: here, there and everywhere? Philosophical Transactions of the Royal Society B, 370, 20140167.

Trinh, A-T., Harvey-Girard, E., Teixeira, F. and Maler, L. (2015). Cryptic laminar and columnar organization in the dorsolateral pallium of a weakly electric fish. Journal of Comparative Neurology, 524, 408-428.

Uceda, S., Ocaña, F. M., Martín-Monzón, I., Rodríguez-Expósito B., Durán, E. and Rodríguez, F. (2015). Spatial learning-related changes in metabolic brain activity contribute to the delimitation of the hippocampal pallium in goldfish. Behavioral Brain Research, 292, 403-408.

van Boxtel, J. J. A., Tsuchiya, N. and Koch, C. (2010). Consciousness and attention: on sufficiency and necessity. Frontiers in Psychology, 1, 217.

Vargas, J. P., Bingman, V. P., Portavella, M. and Lopez, J. C. (2006). Telencephalon and geometric space in goldfish. European Journal of Neuroscience, 24, 2870-2878.

Vargas, R., Thorsteinsson, H. and Karlsson, K. A. (2012). Spontaneous neural activity of the anterodorsal lobe and entopeduncular nucleus in adult zebrafish: a putative homologue of hippocampal sharp waves. Behavioral Brain Research, 229, 10-20.Venegas, H. and Ito, 
H. (1983). Morphological aspects of the teleostean visual system: a review. Brain Research Reviews, 287, 117-137.

Weiss, C. and Disterhoft, J. F. (2015). The impact of hippocampal lesions on trace eyeblink conditioning and forebrain-cerebellar interactions. Behavioral Neuroscience, 129, 512522.

White, G. E. and Brown C. (2015). Cue choice and spatial learning ability are affected by habitat complexity in intertidal gobies. Behavioral Ecology, 26, 178-184.

Yamamoto, N. and Ito, H. (2008). Visual, lateral line, and auditory ascending pathways to the dorsal telencephalic area through the rostrolateral region of the lateral preglomerular nucleus in cyprinids. Journal of Comparative Neurology, 508, 615-647.

Call for Commentary: Animal Sentience publishes Open Peer Commentary on all accepted target articles. Target articles are peer-reviewed. Commentaries are editorially reviewed. There are submitted commentaries as well as invited commentaries. Commentaries appear as soon as they have been reviewed, revised and accepted. Target article authors may respond to their commentaries individually or in a joint response to multiple commentaries. Instructions: http://animalstudiesrepository.org/animsent/guidelines.html 


\title{
UQÀM/ISC Cognitive Science Summer School June 26 - July 6 2018, Montreal, Canada
}

\author{
The Other Minds Problem: Animal Sentience and Cognition
}

Overview. Since Descartes, philosophers know there is no way to know for sure what - or whether — others feel (not even if they tell you). Science, however, is not about certainty but about probability and evidence. The 7.5 billion individual members of the human species can tell us what they are feeling. But there are 9 million other species on the planet (20 quintillion individuals), from elephants to jellyfish, with which humans share biological and cognitive ancestry, but not one other species can speak: Which of them can feel — and what do they feel? Their human spokespersons - the comparative psychologists, ethologists, evolutionists, and cognitive neurobiologists who are the world's leading experts in "mind-reading" other species -- will provide a sweeping panorama of what it feels like to be an elephant, ape, whale, cow, pig, dog, bat, chicken, fish, lizard, lobster, snail: This growing body of facts about nonhuman sentience has profound implications not only for our understanding of human cognition, but for our treatment of other sentient species.

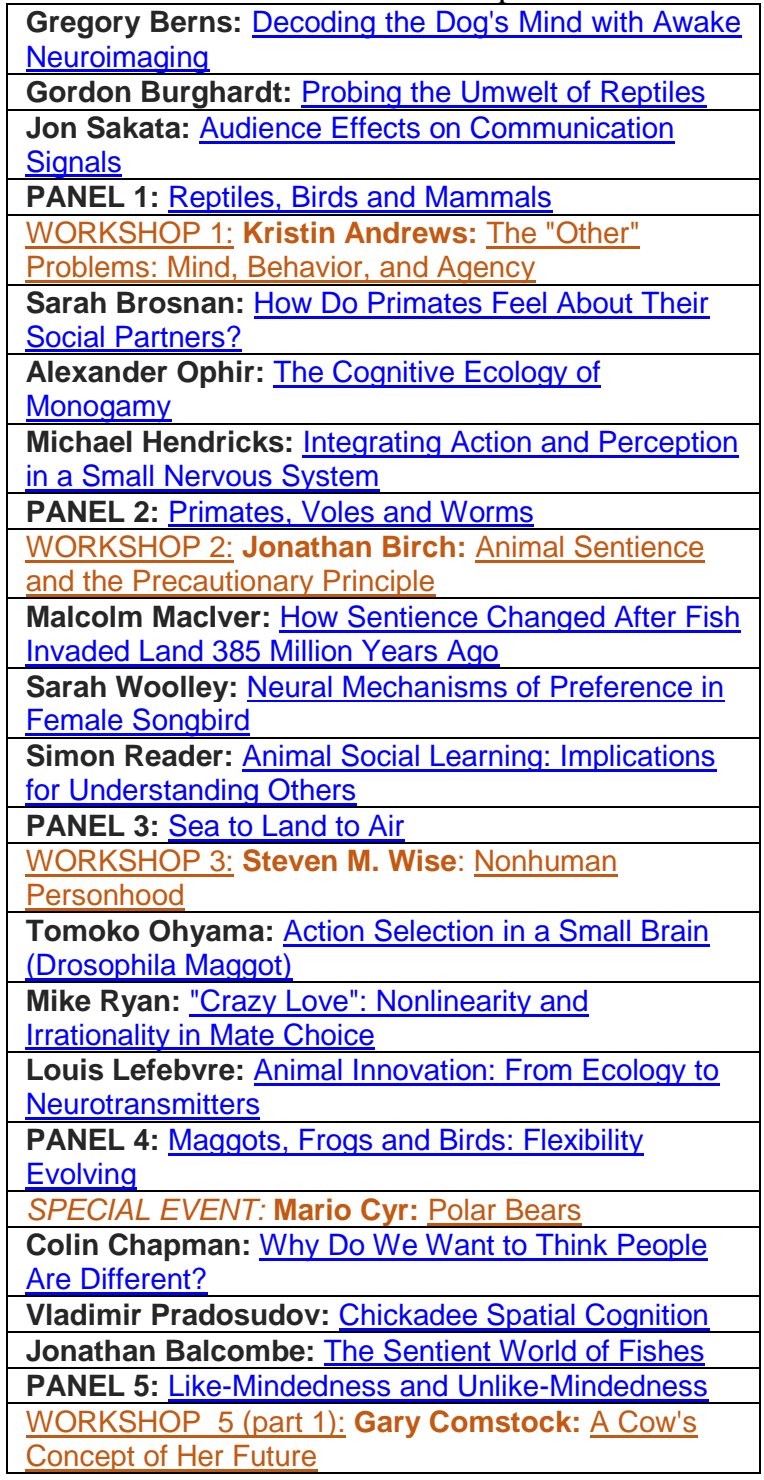

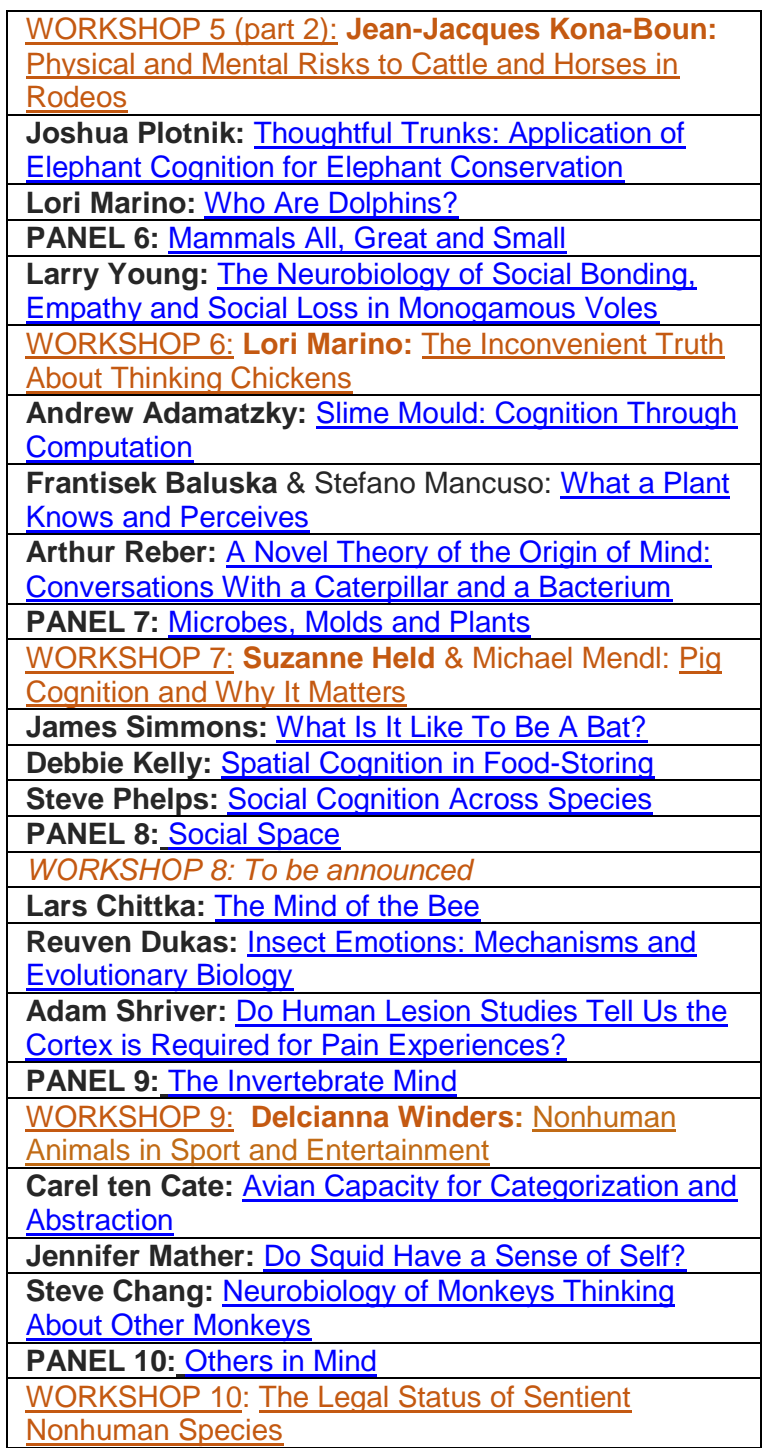

